\title{
Dok. 3. \\ Europa 2020. Strategia na rzecz inteligentnego i zrównoważonego rozwoju sprzyjającego włączeniu społecznemu ${ }^{1}$
}

\begin{abstract}
KOMISJA EUROPEJSKA Bruksela, 3.3.2010 KOM (2010) 2020 wersja ostateczna KOMUNIKAT KOMISJI EUROPA 2020
\end{abstract}

\section{Słowo wstępne}

Rok 2010 musi być rokiem nowego poczatku. Moim pragnieniem jest, aby Europa wyszła z kryzysu gospodarczego i finansowego silniejsza. Na przykładzie światowych skutków kryzysu finansowego wyraźnie widać, że warunki gospodarcze zmieniaja się szybciej niz sytuacja polityczna. Musimy zaakceptować fakt, że zwiększona wspólzależność gospodarcza wymaga bardziej zdecydowanych i spójnych działań również na poziomie politycznym. Przez ostatnie dwa lata miliony ludzi stracity prace, wzrosto zadluzenie, które będzie wyrównywane przez lata, a nasza spójność spoleczna została wystawiona na próbę. Te dwa lata ujawnity również pewne podstawowe prawdy o problemach, z jakimi boryka się europejska gospodarka. Jednocześnie gospodarka światowa zmierza naprzód. Przyszlość Europy zależy od tego, co teraz zrobimy.

Kryzys byl dzwonkiem alarmowym, dzięki któremu zorientowaliśmy się, że jeśli niczego nie zmienimy, skażemy się na stopniowa utratę znaczenia i spadniemy do drugiej ligi nowego światowego porzadku. Dla Europy nadszedt moment prawdy i czas na działania stanowcze i ambitne.

Naszym priorytetem krótkoterminowym jest pomyślne wyjście z kryzysu. Trudny okres jeszcze się nie skończyl, ale nie ma watpliwości, że sobie poradzimy. Postęp jest już odczuwalny w likwidowaniu ztych aktywów, w korygowaniu rynków finansowych, a także jeśli chodzi o porozumienie co do konieczności silnej koordynacji polityki $w$ strefie euro.

Jednak aby zbudować zrównoważonq przyszlość, musimy już teraz wyjść poza horyzont celów krótkoterminowych. Europa musi wrócić na ścieżke rozwoju, a następnie na niej pozostać. Taki jest cel strategii Europa 2020. Jej założenia to więcej miejsc pracy $i$ wyższy standard życia. Strategia pokazuje, że Europa może się rozwljać w sposób inteligentny i zrównoważony, może sprzyjać wtaczeniu spotecznemu, umie znaleźć sposób na stworzenie nowych miejsc pracy i określić kierunek rozwoju naszych spoleczeństw.

Europejscy przywódcy wyciagnęli z kryzysu podobne wnioski. Wszyscy zgadzamy się również co do tego, że nowe wyzwania sq bardzo pilne i teraz wspólnie staramy się stawić im czola. Europa ma wiele silnych stron: zdolnych pracowników, solidna baze technologicznq i przemystowa, rynek wewnętrzny i wspólnq walute, które pomogly nam

1 Analiza zob. art. M. Kubickiej. 
przetrwać zalamanie, oraz wypróbowanq spolecznq gospodarkę rynkowq. Musimy wierzyć w nasze możliwości wytyczenia ambitnego programu, a nastęnie uruchomić wszystkie wysitki, aby go zrealizować.

Komisja proponuje pięć wymiernych celów UE na rok 2020, które nadadza kierunek calemu procesowi i zostana przełożone na cele krajowe. Obejmujq one zatrudnienie, badania i innowacje, zmiany klimatu i energię, edukację oraz walkę z ubóstwem. Pokazuja kierunek, w którym powinniśmy zmierzać, i będq miarq naszego sukcesu. Cele te sq ambitne, ale leżq w naszym zasięgu. Towarzyszq im konkretne propozycje, majace zagwarantować ich osiagnięcie. Projekty przewodnie przedstawione w niniejszym dokumencie sq dowodem zdecydowanej woli dziatania UE. Mamy do dyspozycji potężne narzędzia w postaci nowych metod zarzqdzania finansami, wspartych rynkiem wewnętrznym, mamy budżet, wymianę handlowq $i$ zewnętrzna politykę gospodarczq oraz trwate zasady unii gospodarczej $i$ walutowej.

Warunkiem naszego powodzenia jest pelne zaangażowanie europejskich przywódców i instytucji. Do realizacji nowej strategii potrzebne sq skoordynowane działania w calej Europie, obejmujace również partnerów spolecznych i przedstawicieli spoteczeństwa obywatelskiego. Tylko dzięki współpracy Unia może przezwyciężyć kryzys $i$ wyjść z niego wzmocniona. Dysponujemy nowymi narzędziami i mamy nowe ambicje. Nadszedl czas, by je wspólnie urzeczywistnić.

José Manuel BARROSO

\section{STRATEGIA EUROPA 2020}

\section{Streszczenie}

Europę czeka czas zmian. Kryzys zniweczył wyniki wielu lat postępu gospodarczego i społecznego oraz odsłonił strukturalne słabości europejskiej gospodarki. Jednocześnie świat zmienia się bardzo szybko, a długofalowe problemy, takie jak globalizacja, rosnące zapotrzebowanie na ograniczone zasoby i starzenie się społeczeństw, stają się coraz bardziej naglące. Europa musi zatroszczyć się o swoją przyszłość.

Europa może odnieść sukces, jeśli będzie działać wspólnie, jako Unia. Potrzebujemy strategii, dzięki której wyjdziemy z kryzysu silniejsi, gospodarka UE stanie się inteligentna i zrównoważona, będzie sprzyjać włączeniu społecznemu, będzie się mogła pochwalić wysokimi wskaźnikami zatrudnienia i wydajności oraz większą spójnością społeczną. Europa 2020 to wizja społecznej gospodarki rynkowej dla Europy XXI wieku.

Strategia Europa 2020 obejmuje trzy wzajemnie ze sobą powiązane priorytety:

- rozwój inteligentny: rozwój gospodarki opartej na wiedzy i innowacji;

- rozwój zrównoważony: wspieranie gospodarki efektywniej korzystającej z zasobów, bardziej przyjaznej środowisku i bardziej konkurencyjnej;

- rozwój sprzyjający włączeniu społecznemu: wspieranie gospodarki o wysokim poziomie zatrudnienia, zapewniającej spójność społeczną i terytorialna. 
UE musi określić, gdzie chce się znaleźć w roku 2020. W tym celu Komisja proponuje wytyczenie kilku nadrzędnych, wymiernych celów UE:

- wskaźnik zatrudnienia osób w wieku 20-64 lat powinien wynosić 75\%;

- na inwestycje w badania i rozwój należy przeznaczać 3\% PKB Unii;

- należy osiagnąć cele „20/20/20” w zakresie klimatu i energii (w tym ograniczenie emisji dwutlenku węgla nawet o $30 \%$, jeśli pozwolą na to warunki);

- liczbę osób przedwcześnie kończących naukę szkolną należy ograniczyć do $10 \%$, a co najmniej $40 \%$ osób z młodego pokolenia powinno zdobywać wyższe wykształcenie;

- liczbę osób zagrożonych ubóstwem należy zmniejszyć o $20 \mathrm{mln}$.

Powyższe wymierne cele są ze sobą wzajemnie powiązane i to właśnie od ich osiaggnięcia zależeć będzie nasz sukces. Aby każde państwo członkowskie mogło dopasować strategię Europa 2020 do swojej szczególnej sytuacji, Komisja proponuje, aby powyższe wymierne cele unijne przełożyć na krajowe cele i metody działania.

Powyższe cele szczegółowe wpisują się w realizację trzech ogólnych priorytetów - rozwoju inteligentnego, zrównoważonego i sprzyjającego włączeniu społecznemu. Ich lista nie jest jednak wyczerpująca: aby je urzeczywistnić, potrzebne będą liczne działania prowadzone na poziomie krajowym, unijnym i międzynarodowym. Komisja przedstawia siedem projektów przewodnich, które umożliwią postępy w ramach każdego z priorytetów tematycznych:

- „Unia innowacji” - projekt na rzecz poprawy warunków ramowych i dostępu do finansowania badań $\mathrm{i}$ innowacji, tak by innowacyjne pomysły przeradzały się $\mathrm{w}$ nowe produkty i usługi, które z kolei przyczynią się do wzrostu gospodarczego i tworzenia nowych miejsc pracy;

- „Młodzież w drodze” - projekt na rzecz poprawy wyników systemów kształcenia oraz ułatwiania młodzieży wejścia na rynek pracy;

- „Europejska agenda cyfrowa” - projekt na rzecz upowszechnienia szybkiego Internetu i umożliwienia gospodarstwom domowym i przedsiębiorstwom czerpania korzyści z jednolitego rynku cyfrowego;

- „Europa efektywnie korzystająca z zasobów” - projekt na rzecz uniezależnienia wzrostu gospodarczego od wykorzystania zasobów, przejścia na gospodarkę niskoemisyjną, większego wykorzystania odnawialnych źródeł energii, modernizacji transportu oraz propagowania efektywności energetycznej;

- „Polityka przemysłowa w erze globalizacji” - projekt na rzecz poprawy otoczenia biznesu, szczególnie w odniesieniu do MŚP, oraz wspierania rozwoju silnej i zrównoważonej bazy przemysłowej, przygotowanej do konkurowania na rynkach światowych;

- „Program na rzecz nowych umiejętności i zatrudnienia” - projekt na rzecz modernizacji rynków pracy i wzmocnienia pozycji obywateli poprzez rozwój kwalifikacji przez całe życie w celu zwiększenia współczynnika aktywności zawodowej i lepszego dopasowania popytu do podaży na rynku pracy, między innymi dzięki mobilności sily roboczej;

- „Europejski program walki z ubóstwem” - projekt na rzecz zapewnienia spójności społecznej $\mathrm{i}$ terytorialnej, tak aby korzyści płynące ze wzrostu gospodarczego i zatrudnienia były szeroko dostępne, a osoby ubogie i wykluczone społecznie mogły żyć godnie i aktywnie uczestniczyć w życiu społeczeństwa. 
W realizację siedmiu powyższych projektów przewodnich będzie zaangażowana zarówno Unia Europejska, jak i państwa członkowskie. Do rozwiązania największych problemów i osiagnięcia celów strategii Europa 2020 w pełni wykorzystane zostaną instrumenty, jakimi dysponujemy na poziomie UE, przede wszystkim jednolity rynek, instrumenty finansowe i narzędzia polityki zewnętrznej. W pierwszej kolejności Komisja musi określić, co jest niezbędne, aby przygotować wiarygodną strategię wyjścia z kryzysu, kontynuować reformę systemu finansowego, przeprowadzić konsolidację budżetową na potrzeby dhugofalowego wzrostu gospodarczego oraz zwiększyć koordynację działań w ramach unii gospodarczej i walutowej.

Do osiagnięcia zaplanowanych wyników będziemy potrzebować silniejszego modelu zarządzania gospodarczego. Strategia Europa 2020 będzie się opierać na dwóch filarach: przedstawionym powyżej podejściu tematycznym, łączącym ogólne priorytety i służące ich realizacji wymierne cele, oraz na sprawozdaniach państw członkowskich, które mają pomóc im w opracowaniu własnych strategii powrotu do trwałego wzrostu i stabilnych finansów publicznych. Na poziomie UE przyjęte zostaną zintegrowane wytyczne, obejmujące unijne priorytety ogólne i wymierne cele. Poszczególnym państwom członkowskim przekazane zostaną zalecenia. W przypadku niepodjęcia odpowiednich działań przewiduje się możliwość wystosowania ostrzeżenia. Podsumowanie osiagnięć strategii Europa 2020 i ocena paktu stabilności i wzrostu będą prowadzone jednocześnie, jednak instrumenty te będą funkcjonować niezależnie od siebie i zachowana zostanie integralność paktu.

Sercem strategii i instytucją całkowicie zaangażowaną w jej realizację będzie Rada Europejska. Komisja będzie nadzorować postępy w osiąganiu wytyczonych celów, ułatwiać wymianę polityczną oraz przedstawiać wnioski legislacyjne konieczne do nadawania właściwego kierunku i realizacji projektów przewodnich. Zadaniem Parlamentu Europejskiego będzie zmobilizowanie obywateli oraz współudział w uchwaleniu najważniejszych inicjatyw legislacyjnych. Takie partnerskie podejście powinno objąć również komitety UE, parlamenty narodowe, władze krajowe, lokalne i regionalne, partnerów społecznych oraz inne zainteresowane podmioty i przedstawicieli społeczeństwa obywatelskiego, tak aby wszyscy wzięli udział w realizacji przedstawionej tu wizji.

Komisja proponuje, aby Rada Europejska w marcu przyjęła ogólny kształt strategii i wymierne cele UE, a w czerwcu zatwierdziła szczegółowe parametry strategii, w tym zintegrowane wytyczne i cele krajowe. Aby strategia Europa 2020 mogła przynieść oczekiwane rezultaty, Komisja liczy również na uwagi i wsparcie Parlamentu Europejskiego.

\section{CZAS ZMIAN}

Kryzys zniweczył wyniki długotrwałych postępów Obecny kryzys gospodarczy nie miał w czasach naszego pokolenia precedensu. Nieprzerwany postęp pod względem wzrostu gospodarczego i rosnącego zatrudnienia, towarzyszący nam przez ostatnie dziesięciolecie, został zaprzepaszczony - PKB skurczył się w 2009 r. o 4\%, produkcja przemysłowa spadła do poziomu z lat 90-tych, a 23 miliony osób (czyli 10\% aktywnej zawodowo ludności UE) jest bez pracy. Kryzys był szokiem dla milionów obywateli i ujawnił pewne fundamentalne słabości naszej gospodarki. 
Z powodu kryzysu trudniejsze będzie również zagwarantowanie wzrostu gospodarczego w przyszłości. Przeszkodą w uzdrowieniu gospodarki jest wciąż słaba kondycja naszego systemu finansowego, przez co przedsiębiorstwa i gospodarstwa domowe mają trudności z zaciąganiem kredytów, ostrożnie podchodzą do wydatków i inwestycji. Bardzo ucierpiały nasze finanse publiczne - deficyt budżetowy wynosi średnio 7\% PKB, a poziom długu przekracza $80 \%$ PKB. Dwa lata kryzysu przekreśliły 20 lat konsolidacji budżetowej. Kryzys zmniejszył nasz potencjał wzrostu o połowę. Wiele projektów inwestycyjnych, talentów i pomysłów najprawdopodobniej przepadnie z powodu niepewności, słabego popytu i braku finansowania.

Odsłonięte zostały strukturalnie słabe punkty Europy. Najpilniejszym zadaniem jest wyjście z kryzysu, jednak nie należy ulec pokusie powrotu do sytuacji sprzed kryzysu. W porównaniu z resztą świata, Europa, nawet przed kryzysem, w wielu obszarach nie rozwijała się w wystarczającym tempie:

- średnia stopa wzrostu w Europie była strukturalnie niższa w porównaniu z naszymi największymi partnerami gospodarczymi, głównie z uwagi na różnice w poziomach wydajności, rosnące w ciągu ostatniego dziesięciolecia. Wynika to w dużym stopniu $\mathrm{z}$ różnic w strukturach biznesowych, niższego poziomu inwestycji w działalność badawczo-rozwojową i innowacje, niewystarczającego wykorzystania technologii informacyjno-komunikacyjnych, niechęci części naszych społeczeństw do wprowadzania innowacji, trudności w dostępie do rynku i mniej dynamicznego otoczenia biznesu;

- mimo postępów, wskaźniki zatrudnienia w Europie - średnio 69\% dla osób w wieku 20-64 lat - są wciąż znacznie niższe niż w innych częściach świata. Pracuje tylko $63 \%$ kobiet, podczas gdy zatrudnienie mężczyzn wynosi $76 \%$. Spośród osób starszych (osoby w wieku 55-64 lat) zatrudnionych jest 46\% - dla porównania, w Stanach Zjednoczonych i Japonii wskaźnik ten wynosi $62 \%$. Ponadto Europejczycy pracują średnio $10 \%$ czasu mniej niż pracownicy w USA lub Japonii;

- społeczeństwa starzeją się coraz szybciej. Wraz z odchodzeniem na emeryturę pokolenia wyżu demograficznego liczba osób aktywnych zawodowo zacznie się w UE zmniejszać począwszy od 2013/2014 r. Liczba osób w wieku powyżej 60 lat rośnie dziś w tempie dwa razy szybszym niż przed rokiem 2007 , tj. o ok. 2 mln osób rocznie - wcześniej byl to $1 \mathrm{mln}$ rocznie. Mniejsza liczba ludności czynnej zawodowo i wzrost liczby emerytów będzie dodatkowym obciążeniem dla naszych systemów opieki społecznej.

Coraz trudniejsze wyzwania na arenie międzynarodowej Europa musi wzmocnić swoje strukturalnie słabe strony, ale jednocześnie trzeba pamiętać, że cały świat zmienia się bardzo szybko i za dziesięć lat będzie wyglądać zupełnie inaczej:

- nasze systemy gospodarcze są coraz bardziej współzależne. Europa będzie nadal czerpać korzyści z tego, że jej system gospodarczy jest jednym z najbardziej otwartych na świecie, ale konkurencja ze strony krajów rozwiniętych i wschodzących jest coraz ostrzejsza. Kraje takie jak Chiny i Indie poważnie inwestują w badania i technologie, pragnąc, aby ich przedsiębiorstwa znalazły się wyżej w łańcuchu wartości, i dążąc do zdobycia lepszej pozycji w gospodarce światowej. Wszystko to wywiera presję konkurencyjną na niektóre sektory naszej gospodarki, ale każde zagrożenie może przerodzić się w szansę: wraz z rozwojem tych krajów nowe rynki otworzą się także dla wielu firm europejskich; 
- światowy system finansowy wciąż wymaga naprawy. Dostępność łatwych kredytów, krótkowzroczność i nadmierne ryzyko na rynkach finansowych na całym świecie sprzyjały spekulacjom i doprowadziły do wzrostu opartego na bańce finansowej i do poważnej nierównowagi. Europa bierze udział w opracowywaniu globalnych rozwiązań na rzecz skutecznego i stabilnego systemu finansowego;

- wyzwania związane ze zmianami klimatu i zasobami wymagaja zdecydowanych działań.

Uzależnienie od paliw kopalnych, takich jak ropa naftowa, oraz nieefektywne wykorzystywanie surowców wystawiają naszych konsumentów i przedsiębiorców na bolesny szok cenowy, jednocześnie zagrażając naszemu bezpieczeństwu gospodarczemu i przyczyniając się do niekorzystnych zmian klimatu. Wzrost liczby ludności świata z 6 do 9 mld zaostrzy światową konkurencję w zakresie zasobów naturalnych i zwiększy presję na środowisko. UE nie powinna ustawać w nakłanianiu partnerów z całego świata do wspólnego poszukiwania rozwiązania problemów wynikających ze zmian klimatu, jednocześnie realizując swoją uzgodnioną strategię w zakresie klimatu i energii na terytorium całej Unii. Europa musi działać, aby nie utracić znaczenia.

Z kryzysu możemy wynieść następujące doświadczenia:

- systemy gospodarcze 27 państw UE są w dużym stopniu zależne od siebie nawzajem: kryzys uwidocznił ich bliskie związki i wzajemne oddziaływanie, szczególnie w strefie euro. Jak pokazały ostatnie wydarzenia, reformy lub ich brak $w$ jednym kraju mają wpływ na wyniki wszystkich pozostałych. Ponadto na skutek kryzysu i poważnego ograniczenia wydatków publicznych niektóre państwa członkowskie miały problemy z zapewnieniem wystarczającego finansowania podstawowej infrastruktury, nieodzownej w obszarach takich jak transport i energia, nie tylko na potrzeby rozwoju swojej własnej gospodarki, ale również po to, aby móc w pełni uczestniczyć w wewnętrznym rynku;

- współpraca w ramach UE przynosi rezultaty: nasza reakcja na kryzys pokazała, że jesteśmy dużo bardziej skuteczni, jeśli działamy wspólnie. Udowodniliśmy to wspólnymi działaniami na rzecz stabilizacji systemu bankowego i przyjmując Europejski plan naprawy gospodarczej. W dzisiejszym zglobalizowanym świecie żaden kraj nie jest w stanie skutecznie przezwyciężać trudności w pojedynkę;

- EU może zaoferować wartość dodaną na arenie ogólnoświatowej. Będzie jednak miała wpływ na globalną politykę tylko pod warunkiem wspólnego działania. Silniejsza reprezentacja na zewnątrz będzie musiała iść w parze z lepszą koordynacją wewnętrzną.

Kryzys nie był tylko jednorazowym ciosem, po którym można się podnieść i wrócić do wcześniejszych metod działania. Wyzwania, przed jakimi stoi dziś Unia, są dużo większe niż przed recesją, podczas gdy nasze pole manewru jest ograniczone. Co więcej, reszta świata nie stoi z założonymi rękoma. Większa rola grupy G20 dowodzi rosnącego znaczenia gospodarczego i politycznego krajów wschodzących.

Europa stoi przed wyraźną, choć trudną alternatywą. Możemy wspólnie stawić czoła najpilniejszemu wyzwaniu, jakim jest naprawa gospodarcza, oraz innym wyzwaniom długoterminowym - takim jak globalizacja, rosnące zapotrzebowanie na ograniczone zasoby i starzenie się społeczeństw - aby w ten sposób wyrównać najświeższe straty, odzyskać konkurencyjność, zwiększyć poziom wydajności i skierować UE na drogę prowadzącą do dobrobytu (,trwała odbudowa"). 
Możemy też nadal realizować powolne i w większości nieskoordynowane reformy, ryzykując całkowite zaprzepaszczenie dobrobytu i spowolniony wzrost (,spowolniona odbudowa"), co najprawdopodobniej doprowadzi do wysokiego bezrobocia i niepokojów społecznych oraz utraty znaczenia na arenie międzynarodowej (,stracona dekada”).

\section{Trzy scenariusze dla Europy na okres do roku 2020}

Scenariusz 1: trwała odbudowa - Europa całkowicie odzyskuje wcześniejszą dynamikę wzrostu i może się dalej rozwijać.

Scenariusz 2: spowolniona odbudowa - Europa doświadcza stałego spadku dobrobytu i kontynuuje wzrost $\mathrm{z}$ dalekiego bloku startowego.

Scenariusz 3: stracona dekada - Europa doświadcza stałego spadku dobrobytu i traci możliwość przyszłego wzrostu dynamika wzrostu przed kryzysem.

\section{Europa może odnieść sukces}

Europa ma wiele silnych stron: możemy liczyć na talent i kreatywność naszych obywateli, silną bazę przemysłową, energiczny sektor usług, dobrze prosperujące i wysokiej jakości rolnictwo, silne tradycje morskie, jednolity rynek i wspólną walutę, pozycję największego bloku handlowego na świecie i największego beneficjenta bezpośrednich inwestycji zagranicznych. Możemy być dumni również z naszych silnych wartości, instytucji demokratycznych, poważania dla spójności i solidarności gospodarczej, społecznej i terytorialnej, poszanowania środowiska naturalnego, naszej różnorodności kulturowej i poszanowania równouprawnienia, by wymienić tylko kilka elementów. Wiele państw członkowskich UE należy do najbardziej innowacyjnych i rozwiniętych krajów świata. Niezależnie od tego największą szansą Europy na powodzenie jest działanie wspólne, jako Unia.

W przeszłości w obliczu trudności UE i jej państwa członkowskie zdołały stawić czoła problemom. W latach 90-tych w Europie utworzono największy na świecie jednolity rynek ze wspólną walutą. Kilka lat później skończył się podział Europy; do Unii przystąpiły nowe państwa członkowskie, a inne rozpoczęły starania o członkostwo lub bliższe stosunki z Unią. Działania podejmowane przez ostatnie dwa lata w samym środku kryzysu w ramach Europejskiego planu naprawy gospodarczej pomogły zapobiec zapaści gospodarczej, a nasze systemy opieki społecznej chronily obywateli przed jeszcze większym ubóstwem.

Europa potrafi się zmobilizować w chwili kryzysu i dostosować swoją gospodarkę i społeczeństwo do nowej sytuacji. Dziś Europejczycy muszą znowu zmierzyć się ze zmiana, aby zapobiec efektom kryzysu, naprawić strukturalnie słabe punkty Europy i poradzić sobie z coraz poważniejszymi wyzwaniami na arenie międzynarodowej.

Wyjście z kryzysu musi być jednocześnie przejściem do innej gospodarki. Aby nasze pokolenie i kolejne mogły nadal cieszyć się wysokąjakościążycia, opartą na unikatowych europejskich modelach społecznych, musimy zacząć działać już teraz. Potrzebujemy w tym celu strategii, dzięki której gospodarka UE stanie się inteligentna, zrównoważona i będzie sprzyjać włączeniu społecznemu, co zaowocuje wzrostem zatrudnienia i wydajności oraz większą spójnością społeczną. Wszystko to oferuje nam 
strategia Europa 2020. Jest to program dla wszystkich państw członkowskich, który uwzględnia ich różne potrzeby, różne pozycje startowe i inne cechy szczególne, mający na celu pobudzenie wzrostu w całej Unii.

\section{INTELIGENTNY I ZRÓWNOWAŻONY ROZWÓJ SPRZYJAJĄCY WLĄCZENIU SPOEECZNEMU}

\section{Jaka jest nasza wizja Europy w roku 2020?}

U podstaw strategii Europa 2020 powinny leżeć trzy priorytety ${ }^{1}$ :

- rozwój inteligentny - rozwój gospodarki opartej na wiedzy i innowacji;

- rozwój zrównoważony - wspieranie gospodarki efektywniej korzystającej z zasobów, bardziej przyjaznej środowisku i bardziej konkurencyjnej;

- rozwój sprzyjający włączeniu społecznemu - wspieranie gospodarki charakteryzującej się wysokim poziomem zatrudnienia i zapewniającej spójność gospodarczą, społeczną i terytorialną.

Trzy powyższe priorytety są ze sobą wzajemnie powiązane; dają one obraz europejskiej społecznej gospodarki rynkowej w XXI w.

Powszechnie uważa się, że w ramach ukierunkowania naszych działań i dopingowania do postępów, UE powinna uzgodnić ograniczoną liczbę wymiernych celów na rok 2020. Cele te powinny wpisywać się w motyw przewodni, jakim jest inteligentny i zrównoważony rozwój sprzyjający włączeniu społecznemu. Powinny być one mierzalne, odzwierciedlać różnorodność sytuacji, w jakich znajdują się państwa członkowskie, i opierać się na wystarczająco wiarygodnych danych do celów porównawczych. $\mathrm{Na}$ tej podstawie wybrano następujące cele - od ich osiągnięcia zależeć będzie nasz sukces do roku 2020:

- stopa zatrudnienia osób w wieku 20-64 lat powinna wzrosnąć z obecnych $69 \%$ do co najmniej $75 \%$, między innymi wskutek zwiększenia liczby pracujących kobiet i osób starszych oraz lepszej integracji migrantów na rynku pracy;

- obecny cel UE w zakresie inwestycji w działalność badawczo-rozwojową (B+R) wynosi 3\% PKB. Udało się dzięki niemu zwrócić uwagę na to, jak ważne są publiczne i prywatne inwestycje $\mathrm{w} B+\mathrm{R}$, jednak wiąże się on raczej z wielkością wkładu początkowego niż z wywieranym wplywem. Bez wątpienia trzeba poprawić warunki prywatnej działalności badawczo-rozwojowej w UE i temu właśnie służy wiele środków zaproponowanych w niniejszej strategii. Jasne jest również, że tworząc spójne podejście do działalności badawczo-rozwojowej i innowacji, mielibyśmy do dyspozycji większy zakres środków, co miałoby większe przełożenie na działania biznesowe i czynniki pobudzające wydajność. Komisja proponuje, aby utrzymać 3\% cel, a jednocześnie pracuje nad wskaźnikiem, który odzwierciedlałby intensywność działalności badawczo-rozwojowej i innowacyjnej;

1 Zaproponowane zakresy tematyczne spotkaly się z pozytywnym przyjęciem w trakcie konsultacji publicznych przeprowadzonych przez Komisję. Ze szczególami odpowiedzi nadesłanych w toku konsultacji można zapoznać się na stronie: http://ec.europa.eu/eu2020/index_en.htm. 
- emisję dwutlenku węgla należy ograniczyć co najmniej o $20 \% \mathrm{w}$ porównaniu z poziomem z $1990 \mathrm{r}$. lub, jeśli pozwolą na to warunki ${ }^{1}$, nawet o 30\%; należy zwiększyć udział odnawialnych źródeł energii w naszym całkowitym zużyciu energii do $20 \%$ oraz zwiększyć efektywność wykorzystania energii o $20 \%$;

- cel związany z edukacją, dotyczący problemu osób przedwcześnie kończących naukę szkolną, obejmuje ograniczenie wskaźnika przerywania nauki do $10 \% \mathrm{w}$ porównaniu z obecnym poziomem $15 \%$ oraz zwiększenie do 2020 r. odsetka osób w wieku 30-34 lat posiadających wyższe wykształcenie z 31\% do co najmniej 40\%;

- liczbę Europejczyków żyjących poniżej krajowej granicy ubóstwa należy ograniczyć o $25 \%$, co będzie wymagać wydobycia z ubóstwa ponad $20 \mathrm{mln}$ osób ${ }^{2}$.

Powyższe cele są ze sobą wzajemnie powiązane. Na przykład lepsze wykształcenie przekłada się na większe szanse na rynku pracy, a zwiększanie stopy zatrudnienia przyczynia się do zmniejszania ubóstwa. Większe możliwości w zakresie działalności badawczo-rozwojowej i innowacyjnej we wszystkich sektorach gospodarki oraz efektywniejsze korzystanie z zasobów poprawią naszą konkurencyjność i będą sprzyjać tworzeniu nowych miejsc pracy. Dzięki inwestycjom w czyste i niskoemisyjne technologie poprawi się stan środowiska naturalnego, będziemy mogli skuteczniej przeciwdziałać zmianom klimatu oraz zwiększać potencjał w zakresie przedsiębiorczości i zatrudnienia. Całą naszą uwagę powinniśmy poświęcić osiągnięciu tych celów. Zmiana postaw i metod działania w UE, prowadząca do opisanych wyżej wyników, będzie wymagać silnego przywództwa, zaangażowania i skutecznych mechanizmów realizacji.

Przedstawione tu cele są reprezentatywne, a ich lista nie jest wyczerpująca. Pokazują one, jaka powinna być, zdaniem Komisji, ogólna kondycja Unii Europejskiej w 2020 r. pod względem najważniejszych parametrów. Nie jest to podejście polegające na „mierzeniu wszystkich jedną miarą”. Każde państwo członkowskie jest inne, a UE złożona z 27 członków jest dziś dużo bardziej różnorodna niż dziesięć lat temu. Zdaniem Komisji zaproponowane cele są istotne dla wszystkich państw członkowskich, bez względu na ich staż w Unii i różnice w rozwoju i poziomie życia. Inwestycje w działalność B+R i innowacje, w edukację oraz w technologie umożliwiające efektywne korzystanie z zasobów wpłyną korzystnie zarówno na tradycyjne sektory gospodarki i obszary wiejskie, jak i na gospodarki oparte na usługach, w których ceni się wysokie kwalifikacje.

Poprawią one spójność i solidarność gospodarczą, społeczną i terytorialną. Aby każde państwo członkowskie mogło dopasować strategię Europa 2020 do swojej szczególnej sytuacji, Komisja proponuje, aby powyższe cele unijne przełożyć na krajowe cele i metody realizacji, co umożliwi odzwierciedlenie sytuacji panującej w każdym państwie członkowskim oraz tego, na ile ambitnie może się ono włączyé do wspólnych wysiłków na rzecz osiągnięcia wytyczonych celów. W uzupełnieniu do działań państw

1 Na szczycie w dniach 10-11 grudnia 2009 r. Rada Europejska stwierdziła, że UE - w ramach globalnego, kompleksowego porozumienia dotyczącego okresu po roku 2012 - podtrzymuje swoja warunkową ofertę dotyczącą osiagnięcia do 2020 roku 30 -procentowej redukcji w porównaniu z poziomem z 1990 roku, o ile inne kraje rozwinięte zobowiążą się do porównywalnych redukcji emisji, a kraje rozwijające się wniosą odpowiedni wkład na miarę swoich zadań i możliwości.

${ }^{2}$ Za krajowa granicę ubóstwa przyjęto próg $60 \%$ krajowej mediany rozporządzalnego dochodu w każdym państwie członkowskim. 
członkowskich Komisja zaproponuje także szereg ambitnych inicjatyw na poziomie UE, kierujących UE na nową ścieżkę trwalszego rozwoju. Połączone działania UE i poszczególnych krajów powinny się wzajemnie wspierać.

\section{Inteligentny rozwój - gospodarka oparta na wiedzy i innowacji}

Inteligentny rozwój oznacza zwiększenie roli wiedzy i innowacji jako sił napędowych naszego przyszłego rozwoju. Wymaga to podniesienia jakości edukacji, poprawy wyników działalności badawczej, wspierania transferu innowacji i wiedzy w Unii, pełnego wykorzystania technologii informacyjno-komunikacyjnych, a także zadbania o to, by innowacyjne pomysły przeradzały się w nowe produkty i usługi, które przyczyniałyby się do zwiększenia wzrostu, tworzenia nowych miejsc pracy i rozwiązywania problemów społecznych w Europie i na świecie. Jednak aby projekt ten się powiódł, konieczne są również takie elementy jak przedsiębiorczość, środki finansowe oraz uwzględnienie potrzeb użytkowników i możliwości oferowanych przez rynek.

Działania, jakie Europa musi podjać:

- Innowacje: wydatki na działalność badawczo-rozwojową w Europie wynoszą poniżej $2 \%$, podczas gdy w USA jest to $2,6 \%$, a w Japonii 3,4\%; różnica bierze się głównie z niższego poziomu inwestycji sektora prywatnego. Liczy się nie tylko wysokość kwot przeznaczanych na działalność B $+\mathrm{R}$ - Europa musi zastanowić się nad wpływem i strukturą wydatków na badania oraz poprawić warunki prywatnej działalności badawczo-rozwojowej w UE. Połowa różnicy w stosunku do USA wynika z mniejszej liczby europejskich firm w branży zaawansowanych technologii.

- Kształcenie, szkolenie i uczenie się przez całe życie: co czwarty uczeń nie potrafi dobrze czytać, a co siódmy młody człowiek przerywa proces kształcenia i szkolenia przedwcześnie. Około połowa uczniów zdobywa kwalifikacje na średnim poziomie, które jednak często nie zaspokajają potrzeb rynku pracy. Mniej niż jedna trzecia osób między 25 a 34 rokiem życia ma wykształcenie wyższe, w porównaniu z $40 \% \mathrm{w}$ USA i ponad 50\% w Japonii. Zgodnie z rankingiem Uniwersytetu Shanghai Jiao Tong tylko dwa europejskie uniwersytety są pośród 20 najlepszych uczelni świata.

- Społeczeństwo cyfrowe: wartość globalnego rynku technologii informacyjno-komunikacyjnych wynosi $2000 \mathrm{mld}$ EUR; firmy europejskie zaspokajaja tylko jedna czwartą tego popytu. Europa pozostaje w tyle również pod względem szybkiego Internetu, co negatywnie wpływa na jej potencjal innowacyjny, również na obszarach wiejskich, oraz na rozpowszechnianie wiedzy za pośrednictwem sieci i na internetową sprzedaż produktów i usług. Działania podjęte w ramach tego priorytetu uwolnią europejski potencjał innowacyjny, poprawią rezultaty procesu kształcenia oraz jakość i wyniki instytucji edukacyjnych, a także pozwolą wykorzystać gospodarcze i społeczne możliwości społeczeństwa cyfrowego. Ich realizacja powinna przebiegać na poziomie regionalnym, krajowym i unijnym.

\section{Projekt przewodni: „Unia Innowacji”}

Celem projektu jest wykorzystywanie działalności badawczo-rozwojowej i innowacyjnej do rozwiązywania takich problemów jak zmiany klimatu, efektywność ener- 
getyczna i pod względem zasobów, zdrowie oraz zmiany demograficzne. Konieczne jest wzmocnienie każdego elementu procesu innowacji, począwszy od wstępnych projektów badawczych aż po komercyjne wykorzystanie ich wyników.

Na poziomie UE Komisja podejmuje się:

- ukończyć tworzenie europejskiej przestrzeni badawczej, opracować strategiczny program działalności badawczej skoncentrowany wokół takich kwestii jak bezpieczeństwo energetyczne, transport, zmiany klimatu, efektywne korzystanie z zasobów, zdrowie i starzenie się społeczeństw, przyjazne środowisku metody produkcji i gospodarowanie gruntami, a także wzmocnić rolę wspólnego planowania z państwami członkowskimi i regionami;

- poprawić warunki ramowe prowadzenia działalności innowacyjnej przez przedsiębiorstwa (tj. utworzyć jednolity patent UE i specjalny sąd patentowy, poprawić prawodawstwo w obszarze praw autorskich i znaków towarowych, poprawić dostęp MŚP do ochrony praw własności intelektualnej, przyspieszyć opracowywanie standardów interoperacyjnych, poprawić dostęp do kapitału i w pełni wykorzystywać strategie tworzenia popytu, np. poprzez zamówienia publiczne i inteligentne regulacje;

- utworzyć europejskie partnerstwa innowacyjne między podmiotami działającymi na poziomie UE i w państwach członkowskich w celu szybszego opracowywania i wykorzystywania technologii potrzebnych do rozwiązania określonych problemów. Pierwsze takie partnerstwa obejmą następujące kwestie: ,zbudowanie biogospodarki do roku 2020”, ,najważniejsze technologie wspomagające, kształtujące przyszłość europejskiego przemysłu” oraz ,technologie umożliwiające osobom starszym samodzielne życie i aktywne funkcjonowanie w społeczeństwie";

- nieustająco wzmacniać rolę instrumentów UE mających wspierać innowacje (np. funduszy strukturalnych, funduszy rozwoju obszarów wiejskich, badawczo-rozwojowych programów ramowych, programu ramowego na rzecz konkurencyjności i innowacji (CIP), planu EPSTE) między innymi poprzez ściślejszą współpracę z EBI i sprawniejsze procedury administracyjne w celu ułatwienia dostępu do funduszy, szczególnie MŚP, oraz wprowadzenia innowacyjnych mechanizmów zachęcających do inwestowania związanych z rynkiem uprawnień do emisji dwutlenku węgla, szczególnie dla podmiotów szybko rozwijających się;

- wspierać partnerstwa w obszarze wiedzy i umacniać powiązania między światem nauki, biznesu, badań i innowacji, między innymi z wykorzystaniem Europejskiego Instytutu Innowacji i Technologii, oraz wspierać innowacje, między innymi z wykorzystaniem Europejskiego Instytutu Innowacji i Technologii, oraz wspierać przedsiębiorczość, pomagając młodym innowacyjnym przedsiębiorstwom.

Na poziomie krajowym państwa członkowskie będą musiały:

- zreformować krajowe (i regionalne) systemy prowadzenia działalności badawczo-rozwojowej i innowacyjnej, aby sprzyjały one rozwijaniu doskonałości i inteligentnej specjalizacji, zacieśnić współpracę między uczelniami, społecznością badawczą i biznesem, realizować wspólne planowanie, a także poprawić współpracę w obszarach, gdzie UE może zaoferować wartość dodana, i odpowiednio dostosować krajowe procedury finansowania, tak aby zapewnić rozprzestrzenianie się technologii na całe terytorium UE; 
- zapewnić odpowiednią liczbę absolwentów nauk ścisłych, wydziałów matematycznych i inżynieryjnych oraz wprowadzić do programów szkolnych elementy kreatywności, innowacji i przedsiębiorczości;

- promować wydatki na wiedzę, między innymi stosując ulgi podatkowe $i$ inne instrumenty finansowe umożliwiające wzrost prywatnych inwestycji w badania i rozwój.

\section{Projekt przewodni: „Młodzież w drodze”}

Celem projektu jest poprawa wyników i podniesienie atrakcyjności europejskiego szkolnictwa wyższego na arenie międzynarodowej oraz podniesienie jakości wszystkich poziomów kształcenia i szkolenia w UE, łącząc doskonałość z ideą sprawiedliwości, poprzez wspieranie mobilności studentów i stażystów oraz poprawę sytuacji młodzieży na rynku pracy.

Na poziomie UE Komisja podejmuje się:

- zintegrować i usprawnić działanie europejskich programów w zakresie mobilności, współpracy międzyuczelnianej i badawczej (takich jak Erasmus, Erasmus Mundus, Tempus i Marie Curie) i połączyć je z programami i zasobami krajowymi;

- ożywić program modernizacji szkolnictwa wyższego (programów nauczania, zarządzania i finansowania), między innymi poprzez porównywanie wyników uczelni i rezultatów procesu kształcenia w skali globalnej;

- zbadać możliwości propagowania idei przedsiębiorczości z wykorzystaniem programów mobilności dla młodych specjalistów;

- działać na rzecz oficjalnego uznania uczenia się nieformalnego i pozaformalnego;

- zainicjować opracowanie zasad ramowych dotyczących polityki zatrudnienia osób młodych, określających strategię na rzecz zmniejszenia bezrobocia wśród młodzieży. Realizowane wspólnie z państwami członkowskimi i partnerami społecznymi, zasady te powinny sprzyjać wchodzeniu młodzieży na rynek pracy dzięki stażom, praktykom i innym metodom zdobywania doświadczenia zawodowego, w tym również programowi („Twoja pierwsza praca z EURES-em”) mającemu na celu zwiększenie możliwości zatrudnienia młodzieży poprzez sprzyjanie mobilności na terenie UE.

Na poziomie krajowym państwa członkowskie będą musiały:

- zapewnić odpowiedni poziom inwestycji w systemy kształcenia i szkolenia na wszystkich poziomach (od przedszkolnego do wyższego);

- poprawić rezultaty procesu kształcenia, stosując zintegrowane podejście w każdym segmencie systemu (kształcenie przedszkolne, podstawowe, średnie, zawodowe i wyższe), uwzględniając kluczowe kompetencje i dążąc do ograniczenia liczby osób przedwcześnie kończących naukę szkolną;

- zwiększyć otwartość i znaczenie systemów kształcenia poprzez utworzenie krajowej struktury kwalifikacji i lepsze łączenie rezultatów procesu kształcenia z potrzebami rynku pracy;

- ułatwić młodzieży wchodzenie na rynek pracy poprzez zintegrowane działania obejmujące m.in. udzielanie informacji, doradztwo, staże. 


\section{Projekt przewodni: „Europejska agenda cyfrowa”}

Celem projektu jest osiągnięcie trwałych korzyści ekonomicznych i społecznych $\mathrm{z}$ jednolitego rynku cyfrowego płynących z szybkiego i bardzo szybkiego Internetu i aplikacji interoperacyjnych; w praktyce oznacza to szerokopasmowy dostęp do Internetu dla wszystkich do roku 2013, dostęp do łączy o dużo większej prędkości transmisji danych $(30 \mathrm{Mb} / \mathrm{s} \mathrm{i}$ więcej) dla wszystkich do roku 2020 oraz dostęp do łączy o prędkości powyżej $100 \mathrm{Mb} / \mathrm{s}$ dla co najmniej 50\% europejskich gospodarstw domowych.

Na poziomie UE Komisja podejmuje się:

- opracować stabilne ramy prawne pobudzające inwestycje w otwartą i konkurencyjną infrastrukturę szybkiego Internetu i usługi powiązane;

- opracować skuteczną politykę widma radiowego;

- ułatwić wykorzystanie funduszy strukturalnych UE na potrzeby realizacji tego projektu;

- stworzyć faktyczny jednolity rynek treści i usług on-line (co oznacza ponadgraniczny $\mathrm{i}$ bezpieczny unijny rynek zasobów cyfrowych $\mathrm{i}$ usług $\mathrm{w}$ sieci cieszący się dużym zaufaniem, racjonalne ramy prawne wyraźnie regulujące kwestie praw, propagowanie licencji wieloterytorialnych, odpowiednią ochronę i wynagrodzenie właścicieli praw, aktywne wsparcie cyfryzacji bogatego europejskiego dziedzictwa kulturowego oraz stworzenie koncepcji globalnego zarządzania Internetem);

- zreformować fundusze badawcze i innowacyjne oraz zwiększyć wsparcie w obszarze technologii ICT, aby uwypuklić silne strony Europy w zakresie technologii w najważniejszych strategicznych sektorach i stworzyć warunki umożliwiające szybko rozwijającym się MŚP pociągnięcie za sobą rynków wschodzących i pobudzanie innowacji w obszarze technologii informacyjno-komunikacyjnych we wszystkich sektorach;

- propagować powszechny dostęp do Internetu i korzystanie z niego przez wszystkich obywateli europejskich, szczególnie poprzez działania na rzecz podnoszenia umiejętności informatycznych i dostępu do sieci.

Na poziomie krajowym państwa członkowskie będą musiały:

- sporządzić strategie operacyjne dotyczące szybkiego Internetu i kierować środki publiczne, szczególnie fundusze strukturalne, na obszary nie w pełni obsługiwane przez inwestorów prywatnych;

- stworzyć ramy prawne służące koordynacji działań publicznych, aby obniżyć koszty procesu upowszechniania Internetu;

- propagować stosowanie i korzystanie z nowoczesnych usług on-line (takich jak e-administracja, e-zdrowie, inteligentny dom, umiejętności informatyczne, bezpieczeństwo).

Zrównoważony rozwój - wspieranie gospodarki efektywniej korzystającej z zasobów, bardziej przyjaznej środowisku i bardziej konkurencyjnej Zrównoważony rozwój oznacza budowanie zrównoważonej i konkurencyjnej gospodarki efektywnie korzystającej z zasobów, wykorzystując do tego pierwszoplanową pozycję Europy w wyścigu do nowych procesów i technologii, w tym technologii przyjaznych środowisku, przyspieszając wprowadzanie inteligentnych sieci opartych na technologiach ICT, wy- 
korzystując możliwości sieci obejmujących całą UE, a także wzmacniając przewage konkurencyjną europejskiego biznesu, szczególnie sektora produkcji i MŚP, oraz pomagając klientom docenić wartość efektywnego korzystania z zasobów. Dzięki takiemu podejściu Europa będzie mogła prosperować w niskoemisyjnym świecie ograniczonych zasobów, jednocześnie zapobiegając degradacji środowiska, utracie bioróżnorodności i niezrównoważonemu wykorzystywaniu zasobów. Działania te zwiększą również spójność gospodarczą, społeczną i terytorialną.

Działania, jakie Europa musi podjać:

- Konkurencyjność: UE prosperuje dzięki handlowi - eksportuje na cały świat i importuje zarówno surowce, jak i wyroby gotowe. W obliczu ogromnej presji konkurencyjnej na rynkach eksportowych w odniesieniu do coraz większej liczby surowców musimy stać się bardziej konkurencyjni względem naszych głównych partnerów handlowych poprzez zwiększenie wydajności. Będziemy musieli zając się kwestią względnej konkurencyjności w strefie euro i w całej UE. Unia zwykle przodowała pod względem rozwiązań ekologicznych, teraz jednak jej pozycji zagrażają istotni konkurenci, jak Chiny i Ameryka Północna. UE powinna utrzymać prowadzenie na rynku technologii przyjaznych środowisku, co zapewni efektywne korzystanie z zasobów w całej gospodarce, a jednocześnie powinna usuwać przeszkody w działaniu najważniejszych infrastruktur sieciowych, zwiększając w ten sposób konkurencyjność naszego przemysłu;

- Przeciwdziałanie zmianom klimatu: aby osiągnąć cele w obszarze klimatu, musimy w najbliższym dziesięcioleciu ograniczać emisję gazów cieplarnianych znacznie szybciej niż w poprzednim, a także w pełni wykorzystywać możliwości nowych technologii, takich jak wychwytywanie dwutlenku wegla i sekwestracja. Bardziej efektywne korzystanie z zasobów w dużym stopniu przyczyniłoby się do ograniczenia emisji, oszczędności i pobudzenia wzrostu gospodarczego. Dotyczy to wszystkich sektorów gospodarki, nie tylko tych wysokoemisyjnych. Musimy również wzmocnić odporność naszych systemów gospodarczych na zagrożenia związane z klimatem oraz zwiększyć możliwości zapobiegania klęskom żywiołowym i reagowania na nie;

- Czysta i efektywna energia: osiagnnięcie celów w zakresie energii pozwoliłoby nam zaoszczędzić do 2020 r. 60 mld EUR na imporcie ropy naftowej i gazu. Nie są to tylko oszczędności finansowe: chodzi też o nasze bezpieczeństwo energetyczne. Dalsza integracja europejskiego rynku energii może przynieść dodatkowe $0,6 \%$ do $0,8 \%$ PKB. Dzięki osiągnięciu celu UE mówiącego o $20 \%$ energii ze źródeł odnawialnych moglibyśmy stworzyć w UE ponad 600000 miejsc pracy. Jeśli dodamy do tego cel dotyczący $20 \%$ efektywności energetycznej, można mówić już o milionie nowych miejsc pracy. Priorytet ten będzie wymagał od nas takiej realizacji naszych zobowiązań $\mathrm{w}$ zakresie ograniczenia emisji, aby maksymalnie wykorzystać zalety tego procesu i utrzymać jego koszty na jak najniższym poziomie, między innymi poprzez szerzenie innowacyjnych rozwiązań technologicznych. Powinniśmy także dążyć do uniezależnienia wzrostu od wykorzystania energii i budować gospodarkę, która bardziej efektywnie korzysta z zasobów, co nie tylko zapewni Europie przewagę konkurencyjną, ale również zmniejszy jej zależność od zewnętrznych źródeł zaopatrzenia w surowce i towary podstawowe. 


\section{Projekt przewodni: „Europa efektywnie korzystająca z zasobów”}

Celem projektu jest wsparcie zmiany w kierunku niskoemisyjnego $i$ efektywniej korzystającego z zasobów społeczeństwa, które racjonalnie korzysta ze wszystkich swoich zasobów. Będziemy dążyć do uniezależnienia naszego wzrostu gospodarczego od wykorzystania zasobów i energii, do ograniczenia emisji $\mathrm{CO}_{2}$, zwiększenia konkurencyjności oraz działać na rzecz większego bezpieczeństwa energetycznego.

Na poziomie UE Komisja podejmuje się:

- wykorzystać instrumenty finansowe UE (np. rozwój obszarów wiejskich, fundusze strukturalne, program ramowy dotyczący działalności badawczo-rozwojowej, sieci TEN, EBI) jako elementy konsekwentnej strategii finansowania, lączącej publiczne i prywatne środki UE i państw członkowskich;

- poprawić ramy prawne stosowania instrumentów rynkowych (np. handel emisjami, przegląd zasad opodatkowania energii, pomoc państwa, sprzyjanie szerszemu wykorzystaniu ekologicznych zamówień publicznych);

- przedstawić wnioski legislacyjne dotyczące modernizacji sektora transportu i zmniejszenia jego udziału w emisji związków węgla, co przyczyni się do zwiększenia konkurencyjności. Można to osiągnąc poprzez szereg działań, takich jak działania w zakresie infrastruktury (np. wczesne tworzenie infrastruktury sieci mobilności elektrycznej), inteligentne zarządzanie ruchem, lepsza logistyka, dalsze ograniczanie emisji $\mathrm{CO}_{2}$ pojazdów drogowych oraz w sektorze lotniczym i morskim, w tym opracowanie europejskiej inicjatywy ekologicznych samochodów mającej na celu promowanie nowych technologii obejmujących samochody z napędem elektrycznym i hybrydowym, łącząc w tym celu działalność badawczą, opracowanie wspólnych standardów i rozwój niezbędnej infrastruktury;

- przyspieszyć realizację strategicznych projektów z dużą wartością dodaną ze strony Europy, mających na celu rozładowanie największych przeciążeń, przede wszystkim na odcinkach transgraniczncyh i w węzlach intermodalnych (miasta, porty, platformy logistyczne);

- ukończyć tworzenie wewnętrznego rynku energii oraz zrealizować europejski strategiczny plan w dziedzinie technologii energetycznych (plan EPSTE); priorytetem byłoby także wspieranie odnawialnych źródeł energii na jednolitym rynku;

- przedstawić wniosek w sprawie unowocześnienia sieci europejskich, w tym transeuropejskich sieci energetycznych, i ich transformacji w kierunku europejskiej ,super sieci”, sieci inteligentnych i połączeń międzysystemowych, szczególnie połączeń między siecią i odnawialnymi źródłami energii (przy wsparciu funduszy strukturalnych i EBI). Pociagga to za sobą konieczność wspierania projektów inwestycyjnych o dużym strategicznym znaczeniu dla UE w regionie Morza Bałtyckiego, na Bałkanach, w basenie Morza Śródziemnego i w Eurazji;

- przyjąć i zrealizować zmieniony Plan działania na rzecz racjonalizacji zużycia energii i propagować podstawowy program na rzecz efektywnego korzystania z zasobów (wspierając zarówno MŚP, jak i gospodarstwa domowe) z wykorzystaniem funduszy strukturalnych i innych, aby pozyskać nowe środki w oparciu o już działające i bardzo skuteczne innowacyjne modele programów inwestycyjnych. Powinno to

- wykorzystać instrumenty finansowe UE (np. rozwój obszarów wiejskich, fundusze strukturalne, program ramowy dotyczący działalności badawczo-rozwojowej, sieci 
TEN, EBI) jako elementy konsekwentnej strategii finansowania, łączącej publiczne i prywatne środki UE i państw członkowskich;

- poprawić ramy prawne stosowania instrumentów rynkowych (np. handel emisjami, przegląd zasad opodatkowania energii, pomoc państwa, sprzyjanie szerszemu wykorzystaniu ekologicznych zamówień publicznych);

- przedstawić wnioski legislacyjne dotyczące modernizacji sektora transportu i zmniejszenia jego udziału w emisji związków węgla, co przyczyni się do zwiększenia konkurencyjności. Można to osiągnąć poprzez szereg działań, takich jak działania w zakresie infrastruktury (np. wczesne tworzenie infrastruktury sieci mobilności elektrycznej), inteligentne zarządzanie ruchem, lepsza logistyka, dalsze ograniczanie emisji $\mathrm{CO}_{2}$ pojazdów drogowych oraz w sektorze lotniczym i morskim, w tym opracowanie europejskiej inicjatywy ekologicznych samochodów mającej na celu promowanie nowych technologii obejmujących samochody z napędem elektrycznym i hybrydowym, łącząc w tym celu działalność badawczą, opracowanie wspólnych standardów i rozwój niezbędnej infrastruktury;

- przyspieszyć realizację strategicznych projektów z dużą wartością dodaną ze strony Europy, mających na celu rozładowanie największych przeciążeń, przede wszystkim na odcinkach transgraniczncyh i w węzłach intermodalnych (miasta, porty, platformy logistyczne);

- ukończyć tworzenie wewnętrznego rynku energii oraz zrealizować europejski strategiczny plan w dziedzinie technologii energetycznych (plan EPSTE); priorytetem byłoby także wspieranie odnawialnych źródeł energii na jednolitym rynku;

- przedstawić wniosek w sprawie unowocześnienia sieci europejskich, w tym transeuropejskich sieci energetycznych, i ich transformacji w kierunku europejskiej ,super sieci”, sieci inteligentnych i połączeń międzysystemowych, szczególnie połączeń między siecią i odnawialnymi źródłami energii (przy wsparciu funduszy strukturalnych i EBI). Pociagga to za sobą konieczność wspierania projektów inwestycyjnych o dużym strategicznym znaczeniu dla UE w regionie Morza Bałtyckiego, na Bałkanach, w basenie Morza Śódziemnego i w Eurazji;

- przyjąć i zrealizować zmieniony Plan działania na rzecz racjonalizacji zużycia energii i propagować podstawowy program na rzecz efektywnego korzystania z zasobów (wspierając zarówno MŚP, jak i gospodarstwa domowe) z wykorzystaniem funduszy strukturalnych i innych, aby pozyskać nowe środki w oparciu o już działające i bardzo skuteczne innowacyjne modele programów inwestycyjnych. Powinno to przyczynić się do zmiany wzorców produkcji i konsumpcji;

- opracować wizję zmian strukturalnych i technologicznych, jakie będą musiały zajść do roku 2050, abyśmy mogli przejść na gospodarkę niskoemisyjna, efektywnie korzystającą z zasobów i odporną na zmiany klimatu, dzięki czemu UE będzie mogła osiagnąć cele w zakresie ograniczenia emisji i bioróżnorodności. Działania te obejmują zapobieganie klęskom żywiołowym i reagowanie na nie, wykorzystanie do przeciwdziałaniu zmianom klimatu polityki spójności, rolnictwa, rozwoju obszarów wiejskich i polityki morskiej, szczególnie poprzez środki dostosowawcze oparte na bardziej efektywnym korzystaniu z zasobów, co przyczyni się również do zwiększenia światowego bezpieczeństwa żywnościowego. 
Na poziomie krajowym państwa członkowskie będą musiały:

- stopniowo wycofywać dotacje szkodliwe dla środowiska, stosując wyjątki jedynie w przypadku osób w trudnej sytuacji społecznej;

- stosować instrumenty rynkowe, takie jak zachęty fiskalne i zamówienia publiczne, w celu zmiany metod produkcji i konsumpcji;

- stworzyć inteligentne, zmodernizowane i w pełni wzajemnie połączone infrastruktury transportowe i energetyczne oraz korzystać z pełni potencjału technologii ICT;

- zapewnić skoordynowaną realizację projektów infrastrukturalnych w ramach sieci bazowej UE, które będą miały ogromne znaczenie dla efektywności całego systemu transportowego UE;

- skierować uwagę na transport w miastach, które są źródłem dużego zagęszczenia ruchu i emisji;

- wykorzystywać przepisy, normy w zakresie efektywności energetycznej budynków i instrumenty rynkowe takie jak podatki, dotacje i zamówienia publiczne w celu ograniczenia zużycia energii i zasobów, a także stosować fundusze strukturalne na potrzeby inwestycji w efektywność energetyczną w budynkach użyteczności publicznej i bardziej skuteczny recykling;

- propagować instrumenty służące oszczędzaniu energii, które mogłyby podnieść efektywność sektorów energochłonnych, jak np. instrumenty oparte na technologiach informacyjno-komunikacyjnych.

\section{Projekt przewodni: „Polityka przemysłowa w erze globalizacji”}

Kryzys gospodarczy boleśnie uderzył w przemysł, a szczególnie w MŚP. Wszystkie sektory stoją teraz w obliczu problemów związanych z globalizacją i przystosowaniem procesów produkcji i produktów do wymogów niskoemisyjnej gospodarki. Skutki tych problemów będą różne dla różnych sektorów; niektóre będą być może musiały określić się na nowo, jednak przed innymi mogą otworzyć się nowe możliwości. Komisja będzie ściśle współpracować $\mathrm{z}$ zainteresowanymi podmiotami z różnych sektorów (środowiskami biznesu, związkami zawodowymi, środowiskiem akademickim, organizacjami pozarządowymi, stowarzyszeniami konsumenckimi) i opracuje ramy prawne nowoczesnej polityki przemysłowej mające na celu wsparcie przedsiębiorczości, oferujące wskazówki i pomoc w sprostaniu nowym wyzwaniom, wsparcie konkurencyjności europejskiego przemysłu podstawowego, sektora wytwórczego i sektora usług oraz pomoc w wykorzystaniu możliwości, jakie niesie ze sobą globalizacja i gospodarka przyjazna środowisku. Przepisy te będą obejmowały wszystkie elementy coraz bardziej międzynarodowego łańcucha wartości, od surowców aż po usługi posprzedażne.

Na poziomie UE Komisja podejmuje się:

- opracować politykę przemysłową umożliwiającą stworzenie środowiska służącego utrzymaniu i rozwijaniu silnej, konkurencyjnej i zróżnicowanej bazy przemysłowej w Europie oraz wspierającą przejście sektorów wytwórczych na efektywniejsze korzystanie $\mathrm{z}$ energii i zasobów;

- opracować horyzontalne podejście do polityki przemysłowej z wykorzystaniem różnych instrumentów (takich jak tzw. inteligentne regulacje, dostosowane do no- 
wych warunków zamówienia publiczne i reguły konkurencji oraz ustanawianie norm);

- poprawić otoczenie biznesu, szczególnie w odniesieniu do MŚP, między innymi poprzez ograniczenie kosztów prowadzenia działalności gospodarczej w Europie, wspieranie klastrów i ułatwienie niedrogiego dostępu do finansowania;

- wspierać restrukturyzację sektorów znajdujących się w trudnej sytuacji w kierunku rodzajów działalności dobrze rokujących na przyszłość, między innymi poprzez szybkie przesunięcia kwalifikacji do nowych, szybko rozwijających się sektorów i rynków, z wykorzystaniem unijnego systemu pomocy państwa lub Europejskiego Funduszu Dostosowania do Globalizacji:

- wspierać takie technologie i metody produkcji, które pozwalają ograniczyć wykorzystanie zasobów naturalnych, oraz zwiększyć inwestycje w istniejące unijne dobra naturalne;

- wspierać umiędzynarodowienie MŚP;

- zadbać o to, by sieci transportowe i logistyczne umożliwiały sektorowi przemysłu w Unii skuteczny dostęp do jednolitego rynku i rynków międzynarodowych;

- opracować skuteczną politykę kosmiczna, co pozwoli nam zając się niektórymi z najważniejszych problemów globalnych i przede wszystkim zrealizować projekty Galileo oraz globalnego monitoringu środowiska i bezpieczeństwa;

- zwiększyć konkurencyjność europejskiej turystyki;

- dokonać przeglądu przepisów, aby pomóc sektorowi usług i wytwórczemu bardziej efektywnie korzystać z zasobów, między innymi z wykorzystaniem bardziej efektywnych metod recyklingu; poprawić proces ustanawiania norm europejskich i międzynarodowych, aby przyczyniłyby się one do zwiększenia długotrwałej konkurencyjności europejskiego przemysłu. Działania te będą obejmowały komercyjne wykorzystanie i przejmowanie najważniejszych technologii wspomagających;

- wznowić strategię UE propagującą społeczną odpowiedzialność biznesu, która stanowi ważny element zasobów, między innymi z wykorzystaniem bardziej efektywnych metod recyklingu; poprawić proces ustanawiania norm europejskich i międzynarodowych, aby przyczyniłyby się one do zwiększenia długotrwałej konkurencyjności europejskiego przemysłu. Działania te będą obejmowaly komercyjne wykorzystanie i przejmowanie najważniejszych technologii wspomagających;

- wznowić strategię UE propagującą społeczną odpowiedzialność biznesu, która stanowi ważny element zapewnienia sobie długotrwałego zaufania pracowników i konsumentów.

Na poziomie krajowym państwa członkowskie będą musiały:

- poprawić otoczenie biznesu, szczególnie w odniesieniu do innowacyjnych MŚP, między innymi z wykorzystaniem zamówień publicznych mających na celu wspieranie inwestycji;

- poprawić warunki wykonywania praw własności intelektualnej:

- zmniejszyć obciążenie administracyjne przedsiębiorstw i poprawić jakość przepisów w zakresie działalności gospodarczej;

- ściśle współpracować $\mathrm{z}$ zainteresowanymi podmiotami z różnych sektorów (środowiskiem biznesu, związkami zawodowymi, środowiskiem akademickim, organizacjami pozarządowymi, stowarzyszeniami konsumenckimi), aby rozpoznać problemy 
i wspólnie zastanowić się, jak utrzymać silną bazę przemysłową i bazę wiedzy oraz uczynić UE światowym liderem zrównoważonego rozwoju.

\section{Rozwój sprzyjający włączeniu społecznemu - gospodarka charakteryzująca się wysokim poziomem zatrudnienia i zapewniająca spójność gospodarczą, spoleczną i terytorialną}

Rozwój sprzyjający włączeniu społecznemu oznacza wzmocnienie pozycji obywateli poprzez zapewnienie wysokiego poziomu zatrudnienia, inwestowanie w kwalifikacje, zwalczanie ubóstwa oraz modernizowanie rynków pracy, systemów szkoleń i ochrony socjalnej, aby pomóc ludziom przewidywać zmiany i radzić sobie z nimi oraz móc budować spójne społeczeństwo. Ważne jest również, aby korzyści ze wzrostu gospodarczego rozkładały się równo w całej Unii, w tym w regionach najbardziej oddalonych, zwiększając w ten sposób spójność terytorialną. Chodzi o to, aby każdy obywatel przez całe swoje życie miał przed sobą otwarte możliwości. Aby poradzić sobie z problemami starzejącego się społeczeństwa i rosnącej światowej konkurencji, Europa musi w stu procentach wykorzystać potencjał swojej siły roboczej. Jeśli chcemy zwiększyć współczynnik aktywności zawodowej, potrzebne będą strategie na rzecz zwiększenia równouprawnienia płci. Przyczyni się to do większego rozwoju i spójności społecznej.

Działania, jakie Europa musi podjać:

- Zatrudnienie: w związku ze zmianami demograficznymi nasza siła robocza wkrótce się skurczy. W UE pracuje dziś tylko dwie trzecie osób czynnych zawodowo, podczas gdy w USA i Japonii liczba ta wynosi ponad 70\%. Szczególnie niskie są wskaźniki zatrudnienia kobiet i osób starszych. Kryzys dotknął szczególnie ludzi młodych - bezrobocie wynosi wśród nich ponad $21 \%$. Istnieje duże ryzyko, że ludzie bez pracy lub pracujący okazjonalnie stracą swoją pozycję na rynku pracy.

- Umiejętności: ok. $80 \mathrm{mln}$ osób ma niskie lub podstawowe kwalifikacje, a niezależnie od tego z uczenia się przez całe życie korzystają głównie najbardziej wykształceni. Do roku $2020 \mathrm{w}$ kolejnych $16 \mathrm{mln}$ miejsc pracy potrzebne będą wysokie kwalifikacje; jednocześnie liczba miejse pracy wymagających tylko niskich kwalifikacji spadnie o $12 \mathrm{mln}$. Również wydhużona aktywność zawodowa może się wiązać z koniecznością nabywania nowych umiejętności przez całe życie zawodowe.

- Walka z ubóstwem: przed kryzysem zagrożonych ubóstwem było $80 \mathrm{mln}$ osób, z czego $19 \mathrm{mln}$ to dzieci. 8\% ludzi pracujących nie zarabia wystarczająco dużo, aby przeskoczyć próg ubóstwa. Szczególnie zagrożeni są bezrobotni. Realizacja tego priorytetu będzie wymagać modernizacji i wzmocnienia roli naszej polityki w obszarze zatrudnienia, edukacji i szkolenia oraz systemów ochrony socjalnej poprzez zwiększenie współczynnika aktywności zawodowej i ograniczenie strukturalnego bezrobocia, jak również zwiększenie poczucia odpowiedzialności społecznej w sektorze biznesu. W tym względzie duże znaczenie ma zapewnienie dostępu do opieki nad dziećmi i innymi osobami pozostającymi na utrzymaniu osób pracujących. Najważniejszym elementem będzie stosowanie modelu elastycznego rynku pracy i bezpieczeństwa socjalnego (flexicurity) oraz umożliwienie ludziom zdobywania nowych umiejętności w celu przystosowania się do nowych warunków i na wypadek ewentualnych zmian w karierze zawodowej. Dużego wysiłku wymagać będzie walka z ubó- 
stwem i wykluczeniem społecznym oraz zmniejszenie nierówności w obszarze zdrowia, tak aby rozwój przyniósł korzyści wszystkim. Ważne będzie także wspieranie zdrowia i aktywności osób starszych, aby umożliwić osiągnięcie spójności społecznej oraz wyższej wydajności.

\section{Projekt przewodni: „Program na rzecz nowych umiejętności i zatrudnienia”}

Celem projektu jest stworzenie warunków do unowocześnienia rynków pracy w związku z rosnącym poziomem bezrobocia oraz zapewnienie trwałości naszych modeli społecznych. Oznacza to wzmocnienie pozycji obywateli poprzez umożliwienie im zdobywania nowych umiejętności, tak aby obecni i przyszli pracownicy mogli przystosować się do nowych warunków i ewentualnej zmiany kariery, aby ograniczyć bezrobocie i podnieść wydajność siły roboczej.

Na poziomie UE Komisja podejmuje się:

- opracować i zrealizować, wraz z europejskimi partnerami społecznymi, drugi etap programu flexicurity, aby znaleźć metody lepszego radzenia sobie $\mathrm{z}$ transformacją gospodarczą oraz walczyć z bezrobociem i zwiększyć poziom aktywności zawodowej;

- dostosować ramy prawne, zgodnie z zasadami ,inteligentnych regulacji”, do zmieniających się modeli organizacji pracy (np. czas pracy, delegowanie pracowników) oraz do nowych zagrożeń dla zdrowia i bezpieczeństwa w miejscu pracy;

- ułatwiać i wspierać mobilność siły roboczej w UE oraz lepiej dopasowywać popyt i podaż na rynku pracy przy odpowiednim wsparciu finansowym funduszy strukturalnych, a szczególnie Europejskiego Funduszu Społecznego (EFS), oraz wspierać dalekowzroczną i kompleksową politykę migracji zarobkowej, która umożliwiałaby elastyczne zaspokajanie potrzeb rynku pracy;

- zwiększyć potencjał partnerów społecznych i w pełni wykorzystywać możliwości dialogu społecznego do rozwiązywania problemów na wszystkich poziomach (UE, krajowym, regionalnym, sektorowym, poszczególnych przedsiębiorstw), a także wspierać ściślejszą współpracę między instytucjami zajmującymi się rynkiem pracy, m.in. publicznymi służbami zatrudnienia w państwach członkowskich;

- zainicjować opracowanie strategicznych ram prawnych dotyczących współpracy w dziedzinie kształcenia i szkolenia $\mathrm{z}$ udziałem wszystkich zainteresowanych podmiotów. Wynikiem tych działań powinno być przede wszystkim wdrożenie zasad uczenia się przez całe życie (wspólnie z państwami członkowskimi, partnerami społecznymi i ekspertami), między innymi poprzez elastyczne ścieżki edukacyjne w różnych sektorach i na różnych poziomach kształcenia i szkolenia oraz zwiększanie atrakcyjności kształcenia i szkolenia zawodowego. Należy skontaktować się z parterami społecznymi działającymi na poziomie europejskim, aby opracowali oni własną inicjatywę w tym obszarze;

- zapewnić zdobywanie i uznawanie kompetencji koniecznych do kontynuowania nauki i na rynku pracy w toku kształcenia ogólnego, zawodowego, wyższego i kształcenia dorosłych, a także opracować wspólny język i narzędzie operacyjne do celów kształcenia/szkolenia i pracy: europejskie zasady ramowe dotyczące umiejętności, kompetencji i zawodów (ESCO). 
Na poziomie krajowym państwa członkowskie będą musiały:

- zrealizować własne ścieżki w zakresie flexicurity zgodnie z uzgodnieniami Rady Europejskiej, aby zmniejszyć segmentację rynku pracy oraz ułatwiać zmianę i pogodzenie życia zawodowego i rodzinnego;

- analizować i regularnie monitorować skuteczność działania systemów podatkowych i systemów świadczeń, tak aby praca była opłacalna (ze szczególnym uwzględnieniem osób o niskich kwalifikacjach), i jednocześnie usuwać czynniki zniechęcające do pracy na własny rachunek;

- wspierać nowe sposoby utrzymania równowagi między życiem zawodowym a prywatnym, wspierać aktywność osób starszych oraz zwiększyć równouprawnienie płci;

- wspierać i kontrolować skuteczne wprowadzanie w życie wyników dialogu społecznego;

- dodać silnego bodźca do realizacji europejskich ram kwalifikacji poprzez opracowanie krajowych ram kwalifikacji;

- zapewnić zdobywanie i uznawanie kompetencji koniecznych do kontynuowania nauki i na rynku pracy w toku kształcenia ogólnego, zawodowego, wyższego i kształcenia dorosłych, w tym także w toku uczenia się pozaformalnego i nieformalnego;

- utworzyć partnerstwo przedstawicieli świata edukacji i szkoleń oraz przedstawicieli rynku pracy, przede wszystkim włączając partnerów społecznych do planowania potrzeb w zakresie kształcenia i szkolenia;

- zrealizować własne ścieżki w zakresie flexicurity zgodnie z uzgodnieniami Rady Europejskiej, aby zmniejszyć segmentację rynku pracy oraz ułatwiać zmianę i pogodzenie życia zawodowego i rodzinnego;

- analizować i regularnie monitorować skuteczność działania systemów podatkowych i systemów świadczeń, tak aby praca była opłacalna (ze szczególnym uwzględnieniem osób o niskich kwalifikacjach), i jednocześnie usuwać czynniki zniechęcające do pracy na własny rachunek;

- wspierać nowe sposoby utrzymania równowagi między życiem zawodowym a prywatnym, wspierać aktywność osób starszych oraz zwiększyć równouprawnienie płci;

- wspierać i kontrolować skuteczne wprowadzanie w życie wyników dialogu społecznego;

- dodać silnego bodźca do realizacji europejskich ram kwalifikacji poprzez opracowanie krajowych ram kwalifikacji;

- zapewnić zdobywanie i uznawanie kompetencji koniecznych do kontynuowania nauki i na rynku pracy w toku kształcenia ogólnego, zawodowego, wyższego i kształcenia dorosłych, w tym także w toku uczenia się pozaformalnego i nieformalnego:

- utworzyć partnerstwo przedstawicieli świata edukacji i szkoleń oraz przedstawicieli rynku pracy, przede wszystkim włączając partnerów społecznych do planowania potrzeb w zakresie kształcenia i szkolenia.

\section{Projekt przewodni: „Europejski program walki z ubóstwem”}

Projekt dąży do zapewnienia spójności gospodarczej, społecznej i terytorialnej, stanowi kontynuację idei Europejskiego Roku Walki z Ubóstwem i Wykluczeniem 
Społecznym i ma na celu zwiększenie świadomości i uznanie praw podstawowych osób ubogich i wykluczonych społecznie, dając im szansę godnego życia i aktywnego uczestniczenia w życiu społecznym.

Na poziomie UE Komisja podejmuje się:

- zmienić otwartą metodę koordynacji w zakresie wyłączenia społecznego i ochrony socjalnej w platformę współpracy, wzajemnej oceny i wymiany dobrych praktyk oraz $\mathrm{w}$ instrument służący zachęcaniu podmiotów publicznych i prywatnych do zmniejszania wykluczenia społecznego i do podejmowania konkretnych działań, między innymi $z$ wykorzystaniem ukierunkowanego wsparcia z funduszy strukturalnych, a szczególnie EFS;

- opracować i wdrożyć programy propagujące innowacje społeczne na rzecz osób w trudnej sytuacji społecznej, przede wszystkim poprzez dostęp do innowacyjnego kształcenia, szkoleń i możliwości zatrudnienia wśród społeczności znajdujących się w niekorzystnej sytuacji ekonomiczno-społecznej; walczyć z dyskryminacją (np. osób niepełnosprawnych) oraz opracować nowy program na rzecz integracji migrantów i umożliwienia im pełnego wykorzystania własnego potencjału;

- ocenić adekwatność i trwałość systemów ochrony socjalnej i systemów emerytalnych oraz znaleźć sposoby zapewnienia lepszego dostępu do systemów opieki zdrowotnej.

Na poziomie krajowym państwa członkowskie będą musiały:

- propagować wspólne i indywidualne poczucie odpowiedzialności za walkę z ubóstwem i wyłączeniem społecznym;

- opracować i przeprowadzić działania mające na celu rozwiązanie konkretnych problemów grup szczególnie zagrożonych (rodziców samotnie wychowujących dzieci, starszych kobiet, mniejszości, Romów, osób niepełnosprawnych i bezdomnych);

- w pełni wykorzystywać swoje systemy ochrony socjalnej i emerytalne, aby zapewnić odpowiednie wsparcie dochodu i dostęp do opieki zdrowotnej.

\section{BRAKUJĄCE OGNIWA I PUNKTY PRZECIĄŻENIA}

Jeśli chcemy osiągnąć cele strategii, musimy wykorzystać wszystkie obszary polityki, instrumenty i możliwości legislacyjne oraz instrumenty finansowe UE. Aby skoncentrować się na tym zadaniu, Komisja zamierza wzmocnić rolę najważniejszych obszarów polityki i instrumentów, takich jak jednolity rynek, budżet oraz zewnętrzny program gospodarczy UE. Integralną częścią strategii Europa 2020 będą konkretne wnioski legislacyjne mające na celu całkowite wykorzystanie możliwości tych instrumentów.

\subsection{Jednolity rynek XXI wieku}

Silniejszy, lepiej rozwinięty i bardziej rozległy jednolity rynek ma ogromne znaczenie z punktu widzenia wzrostu i tworzenia miejsc pracy. Dzisiejsze tendencje ujawniaja jednak pewne zmęczenie i rozczarowanie integracją w odniesieniu do jednolitego rynku. Kryzys zrodził pokusę gospodarczego nacjonalizmu. Dzięki czujności Komisji i wspólnemu poczuciu odpowiedzialności państw członkowskich nie zeszliśmy na dro- 
ge prowadzacą w kierunku rozpadu. Potrzebujemy jednak nowego impulsu - prawdziwego politycznego zaangażowania - aby wznowić proces tworzenia jednolitego rynku w drodze szybkiego przyjęcia przedstawionych tu inicjatyw. Takie polityczne zaangażowanie będzie wymagało wypełnienia luk, jakie istnieją w jednolitym rynku.

Każdego dnia przedsiębiorcy i obywatele muszą zmagać się z przeszkodami w działalności transgranicznej, mimo tego, że w świetle prawa w Unii istnieje jednolity rynek. Odkrywają że sieci i systemy nie są wystarczająco połączone, a wdrażanie przepisów w obszarze jednolitego rynku jest nierównomierne. Często przedsiębiorcy i obywatele wciąż muszą stosować 27 różnych systemów prawnych, przeprowadzając tę samą transakcję. Podczas gdy nasi przedsiębiorcy ciągle jeszcze zmagają się z codzienną rzeczywistością rozdrobnienia i rozbieżnych przepisów, ich konkurenci z Chin, USA i Japonii mogą czerpać siłę ze swoich dużych rynków krajowych.

Jednolity rynek utworzono przed epoką Internetu, zanim technologie informacyjno-komunikacyjne stały się jedną z głównych sił napędowych wzrostu gospodarczego, a usługi zaczęły odgrywać tak ważną rolę w europejskiej gospodarce. Pojawienie się nowych usług (np. w obszarze treści i mediów, zdrowia, i inteligentnych systemów pomiaru energii) pokazuje ogromny potencjał, który Europa będzie mogła wykorzystać tylko pod warunkiem przezwyciężenia rozdrobnienia, które obecnie blokuje przepływ treści on-line i dostęp do nich dla konsumentów i przedsiębiorców.

Aby wspólny rynek przysłużył się osiągnięciu celów UE 2020, Unia potrzebuje dobrze działających rynków, na których wzrost i innowacje są pobudzane przez konkurencję i możliwości dostępu dla konsumentów. Konieczne jest utworzenie otwartego, jednolitego rynku usług w oparciu o dyrektywę o usługach, przy jednoczesnej dbałości o jakość świadczonych usług. Pelne wdrożenie dyrektywy o usługach mogłoby przynieść zwiększenie obrotów w sektorze usług handlowych o $45 \%$ oraz wzrost bezpośrednich inwestycji zagranicznych o $25 \%$, co powinno zwiększyć PKB o $0,5 \%$ do $1,5 \%$.

Należy poprawić dostęp MŚP do jednolitego rynku. Konieczny jest rozwój przedsiębiorczości, czemu mają służyć konkretne inicjatywy, między innymi uproszczenie prawa spółek (procedury upadłościowe, statut spółki prywatnej itp.) oraz inicjatywy umożliwiające zbankrutowanym przedsiębiorcom ponowne otwarcie działalności. Trzeba również wzmocnić pozycję obywateli, aby umożliwić im pełne uczestnictwo w jednolitym rynku. Wymaga to zwiększenia ich możliwości i zaufania do kupowania towarów i usług zza granicy, szczególnie w Internecie.

Korzystając z narzędzi, jakie oferuje polityka konkurencji, Komisja będzie dbała o to, by jednolity rynek pozostał rynkiem otwartym, dającym przedsiębiorcom równe szanse i zwalczającym protekcjonizm krajowy. Jednak politykę konkurencji można wykorzystać do osiągania celów strategii Europa 2020 w jeszcze większym stopniu. Może ona posłużyć do tego, aby rynki były odpowiednim otoczeniem dla innowacji, na przykład dbając o właściwe wykonywanie praw patentowych i praw własności intelektualnej. Zapobieganie nadużyciom na rynku i antykonkurencyjnym porozumieniom między przedsiębiorstwami sprzyja większej motywacji do działalności innowacyjnej. W osiągnięciu celów strategii mogą również znacząco pomóc przepisy w zakresie pomocy państwa, np. poprzez pobudzanie i wspieranie inicjatyw na rzecz innowacyjnych, efektywnych i bardziej przyjaznych dla środowiska technologii, przy jednoczesnym 
ułatwianiu dostępu do publicznego wsparcia dla inwestycji, kapitału podwyższonego ryzyka $\mathrm{i}$ finansowania działalności badawczo-rozwojowej.

Komisja zaproponuje następujące działania zmierzające do zmniejszenia przeciążeń na jednolitym rynku:

- wzmocnienie struktur służących wdrożeniu zasad jednolitego rynku prawidłowo i w terminie (m.in. rozporządzeń w sprawie sieci, dyrektywy o usługach oraz pakietu legislacyjnego dotyczącego nadzoru finansowego) oraz ich skutecznemu wykonywaniu i szybkiemu rozwiązywaniu ewentualnych problemów;

- kontynuowanie programu inteligentnych regulacji, obejmującego m.in. częstsze wykorzystywanie rozporządzeń zamiast dyrektyw, przeprowadzanie oceny ex-post obowiązujących przepisów, monitorowanie rynku, zmniejszanie obciążeń administracyjnych, usuwanie przeszkód podatkowych, poprawę otoczenia biznesu, szczególnie w odniesieniu do MŚP, oraz wspieranie przedsiębiorczości;

- przystosowanie przepisów unijnych i krajowych do warunków ery cyfrowej w celu poprawy obiegu treści i zwiększenia zaufania konsumentów i przedsiębiorstw. Wymagać to będzie aktualizacji przepisów dotyczących odpowiedzialności, gwarancji, dostaw i rozstrzygania sporów;

- ułatwianie przedsiębiorcom i konsumentom zawierania umów z partnerami z innych krajów UE oraz ograniczanie kosztów tych operacji, przede wszystkim dzięki zharmonizowanym rozwiązaniom $\mathrm{w}$ obszarze umów konsumenckich, europejskim wzorcowym klauzulom umownym oraz dzięki krokom podejmowanym w kierunku utworzenia opcjonalnego europejskiego prawa spółek;

- ułatwianie wykonywania umów i uznawania wyroków sądowych i dokumentów w innych krajach UE w odniesieniu do przedsiębiorstw i konsumentów oraz zmniejszanie kosztów tych operacji.

\subsection{Inwestowanie na rzecz rozwoju: polityka spójności, wykorzystanie budżetu UE i prywatnego kapitalu}

Bardzo ważnym elementem strategii Europa 2020 będzie nadal kwestia spójności gospodarczej, społecznej i terytorialnej, tak aby wykorzystać całą energię i potencjał i skierować je na realizację priorytetów strategii. Polityka spójności i jej fundusze strukturalne są ważne same w sobie, ale oprócz tego są to również istotne mechanizmy umożliwiające osiągnięcie inteligentnego i zrównoważonego rozwoju sprzyjającego włączeniu społecznemu w państwach członkowskich i na poziomie regionalnym.

Kryzys finansowy znacząco obniżył możliwości europejskich przedsiębiorstw i rządów pod względem finansowania inwestycji i projektów innowacyjnych. Do osiągnięcia celów strategii Europa 2020 niezbędne jest takie otoczenie regulacyjne, dzięki któremu rynki finansowe będą jednocześnie skuteczne i bezpieczne. Europa musi także zrobić wszystko, co w jej mocy, aby odpowiednio wykorzystać swoje środki finansowe, szukać nowych możliwości łączenia kapitału prywatnego i publicznego oraz tworzyć innowacyjne instrumenty finansowania niezbędnych inwestycji, w tym partnerstwa publiczno-prywatne (PPP). Pomocne mogą być Europejski Bank Inwestycyjny i Europejski Fundusz Inwestycyjny, przyczyniając się do pozytywnego sprzężenia zwrotnego, dzięki któremu możliwe jest opłacalne finansowanie innowacji i przedsię- 
biorczości począwszy od wczesnych etapów inwestycji aż do wejścia na giełdę, we współpracy z licznymi inicjatywami i programami publicznymi już działającymi na poziomie krajowym.

Również wieloletnie ramy finansowe UE będą musiały odzwierciedlać priorytety długofalowego rozwoju. Komisja zamierza włączyć te priorytety (po tym jak zostaną zatwierdzone) do swoich wniosków legislacyjnych dotyczących następnych wieloletnich ram finansowych, które przedstawi w przyszłym roku. Dyskusja powinna dotyczyć nie tylko wysokości finansowania, ale również kształtu różnych instrumentów (takich jak fundusze strukturalne, fundusze dotyczące rolnictwa i rozwoju obszarów wiejskich, ramowy program badawczy oraz program ramowy na rzecz konkurencyjności i innowacji (CIP)), który umożliwi osiągnięcie celów strategii Europa 2020 i zapewni maksymalne oddziaływanie, skuteczność i wartość dodaną UE. Ważne będzie znalezienie sposobów na zwiększenie oddziaływania budżetu UE - mimo że niewielki, może on jednak działać jak silny katalizator pod warunkiem prawidłowego przeznaczenia środków.

Komisja zaproponuje następujące działania mające na celu opracowanie innowacyjnych rozwiązań finansowania, służących osiaggnięciu celów strategii Europa 2020:

- pełne wykorzystanie możliwości zwiększenia efektywności i skuteczności obecnego budżetu UE poprzez zdecydowane ustalanie priorytetów i lepsze dopasowanie wydatków UE do celów strategii Europa 2020, aby zaradzić obecnemu rozdrobnieniu instrumentów finansowych UE (np. B+R i innowacje, inwestycje w kluczową infrastrukture, $w$ transgraniczne sieci energetyczne i transportowe oraz technologie niskoemisyjne). Należy również w pełni wykorzystać szansę, jaką da nam przegląd rozporządzenia finansowego, aby zwiększyć potencjał innowacyjnych instrumentów finansowych, zapewniając jednocześnie należyte zarządzanie finansami;

- tworzenie nowych instrumentów finansowych, szczególnie we współpracy z EBI/EFI i sektorem prywatnym, w odpowiedzi na niezaspokojone dotąd potrzeby przedsiębiorstw. W ramach zblizającego się planu w zakresie badań i rozwoju Komisja przeprowadzi inicjatywę, we współpracy z EBI/EFI, mającą na celu zgromadzenie dodatkowego kapitału na finansowanie innowacyjnych i szybko rozwijających się przedsiębiorstw;

- urzeczywistnienie skutecznego europejskiego rynku kapitału venture, co niezwykle ułatwi przedsiębiorstwom bezpośredni dostęp do rynków kapitałowych, oraz stworzenie zachęt dla funduszy $z$ sektora prywatnego finansujących nowo powstające przedsiębiorstwa i innowacyjne MŚP.

\subsection{Wykorzystanie instrumentów polityki zewnętrznej}

Ogólnoświatowy rozwój otworzy przed europejskimi eksporterami nowe możliwości konkurencyjny dostęp do ważnych rynków importowych. Aby zwiększyć europejski wzrost gospodarczy, trzeba wykorzystać wszystkie instrumenty polityki zewnętrznej poprzez udział w otwartych i uczciwych rynkach całego świata. Dotyczy to zewnętrznego wymiaru naszych poszczególnych obszarów polityki wewnętrznej (np. energii, transportu, rolnictwa, B+R), ale przede wszystkim makroekonomicznej koordynacji polityki handlowej i międzynarodowej. Otwarta Europa, działająca w ramach międzynarodowych regulacji, to najlepsza droga do czerpania korzyści z globalizacji, prowa- 
dząca do zwiększenia wzrostu i poziomu zatrudnienia. Jednocześnie Europa powinna silniej zaznaczyć swoją pozycję na arenie międzynarodowej, odgrywając przewodnią rolę w ksztaltowaniu przyszłego globalnego porządku gospodarczego na forum G20 i realizując interesy europejskie poprzez aktywne wykorzystanie wszystkich dostępnych narzędzi Źródłem części wzrostu, jakiego będzie potrzebować Europa w następnym dziesięcioleciu, będą musiały być kraje wschodzące. Klasa średnia w tych krajach rośnie i importuje produkty i usługi, które są domeną Unii Europejskiej. UE, największy blok handlowy na świecie, korzysta na swoim otwarciu na świat i z uwagą obserwuje poczynania innych krajów rozwiniętych lub wschodzących, aby przewidzieć przyszłe tendencje lub przystosować się do nich.

Najważniejszym celem w tym kontekście powinno być działanie w ramach WTO oraz utrzymywanie kontaktów dwustronnych w celu zapewnienia europejskim przedsiębiorstwom, w tym MŚP, lepszego dostępu do rynków i równych szans względem naszych konkurentów zewnętrznych. Powinniśmy także skoncentrować i usprawnić nasz dialog w obszarze regulacji, szczególnie w nowych obszarach, takich jak klimat i rozwój przyjazny środowisku, w miarę możliwości zwiększając nasze globalne oddziaływanie poprzez wspieranie równoważności, wzajemnego uznawania i zbieżności w najważniejszych kwestiach regulacyjnych oraz propagowanie przyjmowania naszych zasad i norm.

Strategia Europa 2020 ma znaczenie nie tylko dla krajów Unii - ma ona dużo do zaoferowania także krajom kandydującym i naszym sąsiadom oraz może pomóc im lepiej ukierunkować własne reformy. Rozszerzenie obszaru stosowania zasad UE otworzy nowe możliwości zarówno przed UE, jak i przed jej sąsiadami.

Jednym z najważniejszych celów na najbliższe lata będzie budowanie strategicznych stosunków z krajami wschodzącymi, aby móc razem omawiać kwestie stanowiące przedmiot wspólnego zainteresowania, wspierać współpracę w zakresie regulacji i innych kwestii oraz rozwiązywać problemy dwustronne. Struktura tych stosunków będzie musiała być elastyczna i mieć wymiar raczej polityczny niż techniczny.

W 2010 r. Komisja przygotuje strategię handlową dla Europy 2020, która będzie obejmować:

- nacisk na zamknięcie bieżących wielo- i dwustronnych negocjacji handlowych, szczególnie tych o największym potencjale gospodarczym, oraz na lepsze wykonywanie obowiązujących porozumień ze szczególnym uwzględnieniem pozataryfowych barier handlowych;

- inicjatywy mające na celu otwarcie możliwości handlowych dla sektorów przyszłości, takich jak produkty i technologie przyjazne środowisku oraz produkty i usługi z branży zaawansowanych technologii, a także normalizacja międzynarodowa, szczególnie w obszarach wzrostu;

- propozycje podjęcia strategicznych rozmów na najwyższym szczeblu z najważniejszymi partnerami w celu omawiania strategicznych kwestii takich jak dostęp do rynków, regulacje prawne, nierównowaga w skali światowej, energia i zmiany klimatu, dostęp do surowców, ubóstwo na świecie, edukacja i rozwój. Komisja będzie również działać na rzecz wzmocnienia roli Transatlantyckiej Rady Gospodarczej z USA i dialogu gospodarczego wysokiego szczebla z Chinami oraz zacieśnienia stosunków z Japonią i Rosją: 
- sprawozdanie przedstawiane na wiosennym szczycie Rady Europejskiej, corocznie począwszy od 2011 r., poświęcone barierom w handlu i inwestycjach, określające sposoby poprawy dostępu do rynków i poprawy otoczenia regulacyjnego dla przedsiębiorstw UE.

UE odgrywa ważną rolę na arenie międzynarodowej i poważnie traktuje swoje obowiązki w tym zakresie. Udało jej się wypracować faktyczne partnerstwo z krajami rozwijającymi się na rzecz walki z ubóstwem, wspierania wzrostu i osiągnięcia milenijnych celów rozwoju. Na szczególną uwagę zasługują nasze bliskie stosunki z Afryką, których dalsze zacieśnianie będzie od nas wymagać przyszłych inwestycji. Wszystko to będzie się odbywało w szerszym kontekście bieżących wysiłków na rzecz zwiększenia pomocy rozwojowej, poprawy skuteczności naszych programów pomocowych, przede wszystkim poprzez efektywny podział zadań między Unię i państwa członkowskie, oraz lepszego odzwierciedlenia celów rozwojowych w innych obszarach Unii Europejskiej.

\section{WYJŚCIE Z KRYZYSU: PIERWSZE KROKI W STRONĘ 2020}

W walce $\mathrm{z}$ kryzysem wykorzystano dostępne instrumenty w sposób stanowczy i skumulowany. Polityka budżetowa - we wszystkich możliwych przypadkach - odegrała role ekspansywną i antycykliczną; stopy procentowe obniżono do poziomu najniższego w historii, a sektorowi finansowemu w bezprecedensowy sposób zapewniono płynność. Rządy udzieliły wysokiego wsparcia bankom - czy to poprzez udzielenie gwarancji, dokapitalizowanie, czy też ,wyczyszczenie” zestawień bilansowych z aktywów o obniżonej jakości; pozostałe sektory gospodarki zostały wsparte w ramach tymczasowej i wyjątkowej pomocy państwa. Wszystkie te rozwiązania były i są uzasadnione, nie moga jednak być stosowane stale. Nie można bez końca utrzymywać wysokiego poziomu dhugu publicznego. Realizacja celów strategii Europa 2020 musi opierać się na wiarygodnej strategii wyjścia z kryzysu obejmującej z jednej strony politykę budżetową i monetarną, a z drugiej - wsparcie bezpośrednie udzielane przez rząd sektorom gospodarki, w szczególności sektorowi finansowemu. Ważna jest kolejność poszczególnych rozwiązań. Większa koordynacja polityki gospodarczej poszczególnych państw, szczególnie w strefie euro, powinna doprowadzić do pomyślnego wyjścia z kryzysu.

\subsection{Opracowanie wiarygodnej strategii wyjścia z kryzysu}

W związku z nadal niepewnymi perspektywami gospodarczymi oraz kruchością sektora finansowego nie należy wycofywać środków wsparcia, zanim odbudowana gospodarka nie stanie się samodzielna i zanim nie odzyskamy stabilności finansowej ${ }^{1}$. Zaprzestanie stosowania tymczasowych środków kryzysowych powinno przebiegać w sposób skoordynowany ze świadomością ryzyka wystąpienia niekorzystnych skutków ubocznych we wszystkich państwach członkowskich, a także wzajemnego oddziaływania różnych zastosowanych instrumentów. Należy przywrócić ścisłe zasady dotyczące pomocy państwa, czego początkiem będzie odejście od tymczasowych ram

\footnotetext{
1 Konkluzje ze szczytu Rady Europejskiej w dniach 10-11 grudnia 2009 r.
} 
udzielania pomocy. Tego rodzaju skoordynowane podejście będzie musiało opierać się na następujących zasadach:

- należy zaprzestać bodźców fiskalnych, gdy tylko stworzone zostaną solidne podstawy odbudowy; może to przebiegać w różnym czasie w poszczególnych państwach członkowskich, stąd konieczność ścisłej koordynacji na poziomie UE;

- krótkoterminowe wsparcie dla bezrobotnych może być wycofywane dopiero, gdy osiagnięty zostanie stabilny punkt zwrotny we wzroście PKB, a więc gdy stopa zatrudnienia - z właściwym sobie opóźnieniem - zacznie rosną́;

- stosowania systemów wsparcia sektorowego należy zaprzestać wcześnie, ponieważ osiagnęły one już w pelni zamierzone skutki, a pociagają za sobą duże koszty dla budżetu oraz mogą stanowić czynnik zakłócający funkcjonowanie jednolitego rynku;

- należy kontynuować wspieranie dostępu do źródeł finansowania do momentu pojawienia się jednoznacznych dowodów na to, że warunki działalności gospodarczej całkowicie wrócily do normy;

- zaniechanie wsparcia dla sektora finansowego, poczynając od systemów gwarancyjnych stosowanych przez rządy, będzie zależało od stanu gospodarki jako całości oraz w szczególności od stabilności systemu finansowego.

\subsection{Reforma systemu finansowego}

Podstawowym priorytetem w najbliższym czasie będzie przywrócenie solidnego, stabilnego i zdrowego sektora finansowego, zdolnego do finansowania gospodarki realnej. Będzie to wymagało całkowitej i terminowej realizacji zobowiązań podjętych na forum G20. Przede wszystkim należy osiagnąć następujące cele:

- realizację uzgodnionych reform dotyczących nadzorowania sektora finansowego;

- wypełnienie luk prawnych, promowanie przejrzystości, stabilności i odpowiedzialności za działania, w szczególności w odniesieniu do instrumentów pochodnych i infrastruktury rynkowej;

- wzmocnienie zasad ostrożnościowych, zasad księgowości i zasad ochrony konsumenta dzięki stworzeniu jednolitego europejskiego zbioru przepisów obejmującego odpowiednio wszystkie podmioty działające $w$ sferze finansów i wszystkie rynki finansowe:

- wzmocnienie zarządzania instytucjami finansowymi jako odpowiedź na niedociagnięcia ujawnione podczas kryzysu finansowego w dziedzinie identyfikacji ryzyka i zarządzania nim;

- uruchomienie ambitnej strategii, która w przyszłości pozwoli nam lepiej zapobiegać $\mathrm{i}$ - jeśli zajdzie taka potrzeba - radzić sobie $\mathrm{z}$ ewentualnymi kryzysami finansowymi i która rozważy możliwość odpowiedniego udziału sektora finansowego, z uwzględnieniem szczególnej odpowiedzialności sektora finansowego w trakcie obecnego kryzysu.

\subsection{Przeprowadzenie inteligentnej konsolidacji budżetowej na rzecz osiągnięcia dhugotrwałego wzrostu}

Zdrowe finanse publiczne mają kluczowe znaczenie dla przywrócenia warunków trwałego wzrostu i zatrudnienia - potrzebujemy zatem kompleksowej strategii wyjścia 
z kryzysu. Będzie ona polegała na stopniowym zaniechaniu krótkoterminowego wsparcia kryzysowego i na wprowadzeniu średnio- i dhugoterminowych reform, które doprowadzą do zrównoważenia finansów publicznych i zwiększenia potencjału wzrostu.

Pakt stabilności i wzrostu zapewnia odpowiednie ramy do wdrażania strategii wyjścia z kryzysu z punktu widzenia budżetu, a państwa członkowskie określają takie strategie w swoich programach stabilności i konwergencji. W większości krajów konsolidacja budżetowa powinna rozpocząć się w 2011 r. Proces obniżania deficytów do poziomu niższego niż 3\% PKB powinien zasadniczo zostać zakończony do $2013 \mathrm{r}$. Niemniej jednak w wielu państwach etap konsolidacji być może będzie musiał rozpocząć się przed rokiem 2011, co z kolei powoduje, że w takich przypadkach wycofywanie tymczasowego wsparcia kryzysowego i konsolidacja fiskalna przebiegać będą w tym samym czasie.

Aby zwiększyć unijny potencjał wzrostu i trwałość naszych modeli społecznych, konsolidacja finansów publicznych w kontekście paktu stabilności i wzrostu wymaga określenia priorytetów i dokonania trudnych wyborów: koordynacja na poziomie UE może ułatwić to zadanie państwom członkowskim i pomóc im zaradzić negatywnym skutkom ubocznym. Ważna jest również struktura i jakość wydatków publicznych: programy konsolidacji budżetowej powinny faworyzować elementy wpływające na wzrost gospodarczy, takie jak edukacja i kwalifikacje, badania, rozwój i innowacje, inwestycje w sieci takie jak szybki Internet, wzajemne połączenia energetyczne i transportowe, innymi słowy - elementy z najważniejszych obszarów tematycznych strategii Europa 2020.

Znaczenie ma również strona budżetu dotycząca dochodów, a szczególna uwaga należy sięjakości systemu dochodów/wpływów z podatków. Jeśli wystapi konieczność podniesienia podatków, powinna ona w miarę możliwości zostać połączona ze zmianą systemów podatkowych na bardziej sprzyjające wzrostowi. Tytułem przykładu: należy unikać zwiększania podatku od zatrudnienia, ponieważ wiemy, że w przeszłości przyczynił się on do obniżenia zatrudnienia. Państwa członkowskie powinny dążyć do przeniesienia środka ciężkości z podatku od zatrudnienia na podatki energetyczne i ekologiczne w ramach dążenia do stworzenia systemów podatkowych przyjaznych środowisku.

Konsolidacji budżetowej i długotrwałej stabilności finansowej muszą towarzyszyć ważne reformy strukturalne, w szczególności dotyczące emerytur, opieki zdrowotnej, ochrony socjalnej i systemów edukacji. Administracja publiczna powinna wykorzystać tę sytuację do podniesienia swojej jakości i skuteczności. Polityka zamówień publicznych musi zagwarantować jak najlepsze wykorzystanie środków publicznych, a rynki zamówień publicznych muszą pozostać otwarte dla całej UE.

\subsection{Koordynacja w ramach unii gospodarczej i walutowej}

Dla państw członkowskich strefy euro wspólna waluta zadziałała jak skuteczna ochrona przed wahaniami kursów walut. Jednocześnie jednak kryzys uświadomił nam do jakiego stopnia gospodarki w strefie euro są od siebie wzajemnie zależne, przede wszystkim w obszarze finansów, co zwiększa prawdopodobieństwo wystąpienia negatywnych efektów ubocznych. Różne modele wzrostu spowodowały w niektórych przy- 
padkach nagromadzenie deficytów niemożliwych do sfinansowania, co z kolei wywiera presję na wspólną walutę. Kryzys doprowadził do zwiększenia wyzwań stojących przed strefą euro: stabilności finansów publicznych i potencjalnego wzrostu, destabilizującej roli nierównowagi budżetowej i różnic w konkurencyjności.

Pilne sprostanie tym wyzwaniom w strefie euro ma ogromne znaczenie dla zagwarantowania stabilności oraz zrównoważonego rozwoju sprzyjającego zwiększeniu zatrudnienia. Wymaga to silniejszej koordynacji prowadzonej polityki, w tym:

- ram prawnych dla dokładniejszego i szerszego nadzoru nad państwami strefy euro: oprócz poprawienia dyscypliny budżetowej, nadzorem gospodarczym należy również objąć nierównowagę makroekonomiczną i rozwój konkurencyjności, w szczególności w celu ułatwienia dostosowań wynikających z prowadzonej polityki;

- ram prawnych umożliwiających działanie w obliczu zbliżających się zagrożeń stabilności finansowej strefy euro jako całości;

- odpowiedniej reprezentacji strefy euro na zewnątrz, która umożliwi zdecydowane działania w obliczu światowych wyzwań gospodarczych i finansowych.

Komisja przedstawi wnioski legislacyjne nadające bieg tym pomysłom.

\section{WIDOCZNE WYNIKI: SILNIEJSZE ZARZĄDZANIE}

Strategia Europa 2020 nie doprowadzi do widocznej transformacji bez sprecyzowanych i jasnych celów oraz przejrzystych kryteriów służących ocenie postępów. Będzie to wymagało silnego zarządzenia, wykorzystującego dostępne instrumenty w celu skutecznej i terminowej realizacji strategii.

\subsection{Proponowana struktura strategii Europa 2020}

Na strategię Europa 2020 powinno składać się podejście tematyczne oraz dokładniejszy nadzór nad państwami członkowskimi. Umożliwi to wykorzystanie już istniejących instrumentów koordynacji. Dokładniejszy opis tej struktury przedstawia się następująco:

- Podejście tematyczne skupiałoby się na zagadnieniach wskazanych w pkt 2, a przede wszystkim na osiągnięciu pięciu nadrzędnych, wymiernych celów. Shużyłaby temu głównie strategia Europa 2020 i zawarte w niej inicjatywy przewodnie, które wymagają działań zarówno na poziomie UE, jak i na poziomie państw członkowskich (zob. pkt 2 oraz załączniki 1 i 2). Podejście tematyczne uwzględnia wymiar unijny, w jasny sposób pokazuje wzajemną zależność między gospodarkami państw członkowskich i umożliwia większy wybór konkretnych inicjatyw, które popychają realizację strategii naprzód i ułatwiają osiagnięcie głównych celów unijnych i krajowych.

- Sprawozdania krajowe, stanowiąc dla państw członkowskich pomoc w określaniu i realizacji strategii wyjścia z kryzysu, przyczynią się do osiągnięcia celów strategii Europa 2020, do przywrócenia stabilności makroekonomicznej, rozpoznania przeszkód właściwych każdemu państwu i przywrócenia ich gospodarkom stabilnego wzrostu i finansów publicznych. Sprawozdania te nie będą dotyczyły jedynie polityki budżetowej, ale także najważniejszych zagadnień makroekonomicznych związanych ze wzrostem i konkurencyjnością (np. nierównowagi makroekonomicznej). 
Będą musiały zapewnić jednolite podejście do tworzenia i wdrażania polityki, co jest kluczowe pod względem wsparcia wyborów dokonywanych przez państwa członkowskie, koniecznych w sytuacji ograniczenia finansów publicznych. Szczególną uwagę należy poświęcić funkcjonowaniu strefy euro i wzajemnym zależnościom między państwami członkowskimi.

Aby to osiągnąć, sprawozdania i oceny w ramach strategii Europa 2020 oraz w ramach paktu stabilności i wzrostu będą przeprowadzane jednocześnie, co umożliwi połączenie środków i celów, jednak same instrumenty i procedury będą funkcjonować niezależnie od siebie i zachowana zostanie integralność paktu. Oznacza to, że projekty rocznych programów stabilności i konwergencji, projekty ukierunkowanych programów reform, które każde państwo członkowskie opracuje w celu określenia środków służących ocenie postępów w osiaganiu wyznaczonych przez siebie celów, oraz projekty najważniejszych reform strukturalnych zmierzających do rozwiązania przeszkód na drodze do wzrostu gospodarczego, będą przedstawiane jednocześnie. Oba rodzaje programów, które powinny zawierać wzajemne odniesienia, należy przedłożyć Komisji i innym państwom członkowskim w ostatnim kwartale roku. Europejska Rada ds. Ryzyka Systemowego powinna regularnie przedstawiać sprawozdania dotyczące ryzyka makrofinansowego: sprawozdania te w znacznym stopniu wpływać będą na ocenę ogólna. Komisja dokona oceny przedstawionych programów i postępów w ich realizacji. Szczególną uwagę będzie przykładać do wyzwań związanych z unią gospodarczą i walutową.

Dzięki temu Rada Europejska dysponować będzie informacjami koniecznymi do podejmowania decyzji. W jej rękach znajdą się wyniki analizy gospodarczej i sytuacji dotyczącej zatrudnienia, ogólny obraz budżetu, warunków makrofinansowych oraz postępów w zakresie programów tematycznych państw członkowskich, a dodatkowo przeprowadzi ona przegląd ogólnego stanu unijnej gospodarki.

\section{Zintegrowane wytyczne}

Instytucjonalnym szkieletem strategii Europa 2020 będzie zestaw kilku wytycznych (uwzględniających zagadnienia zatrudnienia oraz szeroko pojętej polityki gospodarczej), które zastapią istniejące obecnie 24 wytyczne. Nowe wytyczne odzwierciedlą decyzje Rady Europejskiej i obejmą uzgodnione cele. Po tym jak, zgodnie z Traktatem, Parlament Europejski wyda opinię na temat wytycznych dotyczących zatrudnienia, wytyczne te powinny otrzymać polityczne poparcie Rady Europejskiej na szczycie w czerwcu, a następnie zostać przyjęte przez Radę. Po przyjęciu wytyczne nie powinny ulegać większym zmianom do 2014 r., co pozwoli skupić się na ich wdrażaniu.

\section{Zalecenia strategiczne}

Zalecenia strategiczne kierowane będą do państw członkowskich zarówno w kontekście sprawozdań krajowych, jak i w ramach podejścia tematycznego strategii Europa 2020. W kontekście nadzoru nad państwami członkowskimi przyjmą one formę opinii w sprawie programów stabilności/konwergencji, zgodnie z rozporządzeniem Rady (WE) nr 1466/97, opatrzonych zaleceniami sporządzanymi na podstawie ogólnych wy- 
tycznych polityki gospodarczej (art. 121 ust. 2). Częśc tematyczna obejmować będzie zalecenia w sprawie zatrudnienia (art. 148) oraz zalecenia dla poszczególnych krajów dotyczące innych wybranych zagadnień tematycznych (np. otoczenia biznesu, innowacji, funkcjonowania jednolitego rynku, energii/zmian klimatu). Oba te elementy mogą być również uwzględniane - w zakresie, w jakim mają skutki makroekonomiczne - w zaleceniach sporządzanych na podstawie ogólnych wytycznych polityki gospodarczej, o których mowa powyżej. Taki zestaw zaleceń ułatwi również zapewnienie spójności między przepisami makroekonomicznymi/budżetowymi a programami tematycznymi.

Zalecenia sporządzane w ramach nadzoru nad państwami członkowskimi będą dotyczyły zagadnień o ogromnym znaczeniu makroekonomicznym oraz dla finansów publicznych, natomiast zalecenia w ramach podejścia tematycznego dostarczać będą szczegółowych wskazówek na temat rozwiązywania problemów makroekonomicznych oraz związanych z zatrudnieniem. Zalecenia te będą stosunkowo szczegółowe i co do zasady przewidywać będą termin, przed upływem którego państwo członkowskie powinno podjać działania (np. dwa lata). Kolejnym krokiem będzie określenie przez dane państwo działań, jakie zostaną podjęte w celu wdrożenia danego zalecenia. Jeśli państwo członkowskie nie dostosuje się w przewidzianym terminie odpowiednio do zalecenia Rady lub podejmie działania niezgodne z udzielonym zaleceniem, Komisja może wystosować ostrzeżenie (art. 121 ust. 4).

\subsection{Podzial ról}

Najważniejsze jest wspólne działanie na rzecz osiągnięcia wyznaczonych celów. W naszych wzajemnie połączonych gospodarkach odpowiedni poziom wzrostu i zatrudnienia może zostać przywrócony jedynie pod warunkiem, że będą do tego dążyć wszystkie państwa członkowskie, uwzględniając sytuację we własnym kraju. Musimy zwiększyć zaangażowanie w ten proces. Rada Europejska na wniosek Komisji powinna zapewniać ogólne wytyczne dla strategii oparte na jednej podstawowej zasadzie: wyraźnej wartości dodanej dla UE. W tym kontekście szczególnie ważna jest rola Parlamentu Europejskiego. Należy również wzmocnić udział zainteresowanych stron na poziomie krajowym i regionalnym oraz udział partnerów społecznych. Szkic przebiegu i harmonogram strategii Europa 2020 zawarto w załączniku 3.

\section{Pełne zaangażowanie Rady Europejskiej}

W przeciwieństwie do obecnej sytuacji, w której Rada Europejska podejmuje działania w procesie decyzyjnym strategii jako ostatnia, to właśnie ona - jako organ zapewniający integrację prowadzonej polityki oraz zarządzający wzajemnymi zależnościami między państwami członkowskimi a EU - powinna nadawać kierunek strategii Europa 2020.

Zachowując prawo ogólnego oglądu procesu wdrażania strategii Europa 2020, na kolejnych posiedzeniach Rada Europejska powinna skupić się na poszczególnych zakresach tematycznych (np. badania i innowacje, kwalifikacje), udzielając wskazówek i dostarczając koniecznych bodźców do działania. 


\section{Rada Ministrów}

Odpowiednie składy Rady będą prowadziły prace nad procesem wdrożenia strategii Europa 2020 i dążyły do osiagnnięcia celów w dziedzinach leżących w zakresie ich odpowiedzialności. W ramach inicjatyw przewodnich państwa członkowskie powinny dążyć do polepszenia wymiany informacji i dobrych praktyk na forum różnych składów Rady.

\section{Komisja Europejska}

Komisja Europejska co roku będzie monitorowała rozwój sytuacji w oparciu o zestaw wskaźników pokazujących ogólny postęp w tworzeniu inteligentnej, ekologicznej gospodarki sprzyjającej włączeniu społecznemu, o wysokiej stopie zatrudnienia, wydajności i spójności społecznej.

Komisja co roku przedstawiać będzie sprawozdanie dotyczące wyników strategii Europa $2020 \mathrm{z}$ naciskiem na postępy w osiąganiu wyznaczonych celów głównych oraz oceniające sprawozdania krajowe i programy stabilności i konwergencji. Część tego procesu będą również stanowić zalecenia strategiczne lub ostrzeżenia, wnioski legislacyjne mające ułatwić osiagnięcie celów strategii oraz szczególna ocena postępów w strefie euro.

\section{Parlament Europejski}

Parlament Europejski powinien odgrywać ważną rolę w opisywanej strategii, nie tylko jako organ prawodawczy, ale również jako siła sprawcza mobilizująca obywateli i parlamenty narodowe. Parlament mógłby na przykład poświęcić swoje następne spotkanie z parlamentami narodowymi debacie na temat swojego udziału w strategii Europa 2020 i przedstawić wspólne stanowisko na wiosennym szczycie Rady Europejskiej.

\section{Wladze krajowe, regionalne i lokalne}

Wszystkie władze krajowe, regionalne i lokalne powinny realizować partnerstwo, ściśle włączając do tego procesu parlamenty, a także partnerów socjalnych oraz przedstawicieli społeczeństwa obywatelskiego, przyczyniających się do opracowania krajowych programów reform oraz ich wdrażania.

Dzięki ustanowieniu stałego dialogu między różnymi poziomami administracji krajowej, unijne priorytety znajdują się bliżej obywateli, co zwiększa zaangażowanie konieczne dla pomyślnej realizacji strategii Europa 2020.

\section{Zainteresowane podmioty i spoleczeństwo obywatelskie}

Do realizacji strategii należy również włączyć Komitet Ekonomiczno-Społeczny oraz Komitet Regionów. Wiele państw członkowskich wspiera wymianę dobrych praktyk, ustalanie kryteriów oraz budowanie sieci kontaktów, które okazały się bardzo skutecznym narzędziem służącym zwiększeniu zaangażowania oraz zwiększeniu dynamiki działania we wprowadzaniu koniecznych reform.

Sukces nowej strategii będzie zatem w głównej mierze zależał od tego, na ile instytucje Unii Europejskiej, państwa członkowskie oraz regiony będą umiały przekonująco 
wyjaśnić, że reformy są nieuniknione i niezbędne do utrzymania obecnej jakości życia i modeli społecznych, a również od tego, jak będą przekazywać swoją wizję Europy i państw członkowskich w 2020 r. i informować o tym, jakiego udziału oczekują od obywateli, środowisk biznesowych i ich organizacji przedstawicielskich. W uznaniu konieczności uwzględnienia różnic krajowych oraz wykształconych tradycji Komisja przedstawi propozycję wspólnych narzędzi komunikacyjnych na potrzeby strategii.

\section{DECYZJE RADY EUROPEJSKIEJ}

Komisja wnosi, aby na swoim wiosennym szczycie w 2010 r. Rada Europejska: - uzgodniła priorytety tematyczne strategii Europa 2020;

- określiła pięć celów głównych, zgodnie z propozycją opisaną w pkt 2 niniejszego dokumentu, wskazując, co Europa chce osiągnąć do 2020 r. w zakresie inwestycji na badania i rozwój, edukacji, energii/zmian klimatu, stopy zatrudnienia oraz zmniejszania ubóstwa; wezwała państwa członkowskie do dialogu z Komisją Europejska, zmierzającego do przełożenia celów unijnych na cele krajowe (z uwzględnieniem sytuacji każdego kraju i różnic na etapie początkowym), które będą przedmiotem decyzji na czerwcowym szczycie Rady Europejskiej;

- wezwała Komisję do przedstawienia wniosków legislacyjnych dotyczących inicjatyw przewodnich oraz wezwała Radę (i jej składy tematyczne) do przyjęcia odpowiednich decyzji w celu ich wdrożenia;

- podjęła decyzję o wzmocnieniu koordynacji polityki gospodarczej w celu zwiększenia pozytywnych wzajemnych oddziaływań oraz lepszego radzenia sobie z problemami na poziomie UE; aby w tym celu zatwierdziła połączenie ocen tematycznych i ocen krajowych zaproponowane w niniejszym komunikacie przy jednoczesnym ścisłym zachowaniu integralności paktu stabilności i wzrostu; położyła szczególny nacisk na wzmocnienie unii monetarnej i walutowej:

- wezwała wszystkie podmioty i zainteresowane strony (np. parlamenty narodowe/regionalne, władze regionalne i lokalne, partnerów społecznych i społeczeństwo obywatelskie, a także obywateli europejskich) do pomocy we wdrażaniu strategii poprzez partnerskie działanie i podejmowanie działań leżących w zakresie ich odpowiedzialności;

- wezwała Komisję do monitorowania postępów i przedkładania corocznego sprawozdania na wiosennym szczycie Rady Europejskiej, na którym przedstawiać będzie przegląd postępów osiągniętych w realizacji wyznaczonych celów, w tym na podstawie kryteriów międzynarodowych, oraz stan wdrożenia projektów przewodnich.

Na kolejnych posiedzeniach:

- po opinii Parlamentu Europejskiego, poparła zaproponowane zintegrowane wytyczne, które stanowią instytucjonalne podstawy strategii;

- zatwierdziła cele krajowe po przeprowadzeniu wzajemnej weryfikacji, mającej na celu zachowanie spójności;

- przedyskutowała poszczególne kwestie, dokonując oceny obecnej sytuacji w Europie oraz rozpatrując możliwość przyspieszenia postępów. Pierwsza debata na temat badań i innowacji - oparta o dane przedstawione przez Komisję - mogłaby odbyć się na szczycie Rady w październiku. 
Zalącznik 1

\section{EUROPA 2020: ZARYS}

NAJWAŻNIEJSZE CELE:

- zwiększyć stopę zatrudnienia osób w wieku 20-64 lat z obecnych 69\% do co najmniej 75\%;

- osiagnać poziom inwestycji w działalność badawczo-rozwojową równy 3\% $\mathrm{PKB}$, przede wszystkim poprzez poprawę warunków inwestowania w $B+R$ przez sektor prywatny i opracowanie nowego wskaźnika umożliwiającego śledzenie procesów innowacji;

- ograniczyć emisję dwutlenku wegla co najmniej o $20 \%$ w porównaniu z poziomem z 1990 r. lub, jeśli pozwolą na to warunki, o 30\%; zwiększyć udział odnawialnych źródeł energii w naszym całkowitym zużyciu energii do $20 \%$ oraz zwiększyć efektywność wykorzystania energii o $20 \%$;

- ograniczyć liczbę osób przedwcześnie kończących naukę szkolną do $10 \%$ z obecnych 15\% oraz zwiększyć odsetek osób w wieku 30-34 lat posiadających wyższe wykształcenie z $31 \%$ do co najmniej $40 \%$;

- ograniczyć liczbę Europejczyków żyjących poniżej krajowej granicy ubóstwa o 25\% poprzez wydobycie z ubóstwa $20 \mathrm{mln}$ osób.

\begin{tabular}{|c|c|c|}
\hline Inteligentny rozwój & Zrównoważony rozwój & $\begin{array}{c}\text { Rozwój sprzyjający włączeniu } \\
\text { spolecznemu }\end{array}$ \\
\hline INNOWACJE & KLIMAT, ENERGIA I MOBILNOŚĆ & ZATRUDNIENIE I UMIEJĘTNOŚCI \\
\hline $\begin{array}{l}\text { Przewodni projekt UE „Unia } \\
\text { innowacji” ma na celu poprawę } \\
\text { warunków ramowych i dostępu } \\
\text { do finansowania badań i inno- } \\
\text { wacji, co powinno wzmocnić } \\
\text { rolę łá́cucha innowacji i zwię- } \\
\text { kszyć poziom inwestycji w } \\
\text { całej Unii. }\end{array}$ & $\begin{array}{l}\text { Przewodni projekt UE „Europa efek- } \\
\text { tywnie korzystająca z zasobów” ma na } \\
\text { celu uniezależnienie wzrostu gospodar- } \\
\text { czego od wykorzystania zasobów poprzez } \\
\text { zmniejszenie udziału emisji wegla } \\
\text { W europejskiej gospodarce, wiekksze wy- } \\
\text { korzystanie odnawiahyych źródel energii, } \\
\text { modernizację transportu i propagowa- } \\
\text { nie efektywności energetycznej. }\end{array}$ & $\begin{array}{l}\text { Przewodni projekt UE „Program na } \\
\text { rzecz nowych umiejętności i zatrudnie- } \\
\text { nia” ma na celu modernizację rynków } \\
\text { pracy poprzez zwiększanie mobilności } \\
\text { siły roboczej oraz rozwijanie kwalifi- } \\
\text { kacji przez całe życie, co powinno pod- } \\
\text { nieśc współczynnik aktywności } \\
\text { zawodowej i lepiej dopasować do sie- } \\
\text { bie popyt i podaż na rynku pracy. }\end{array}$ \\
\hline EDUKACJA & KONKURENCYJNOŚĆ & WALKA Z UBÓSTWEM \\
\hline $\begin{array}{l}\text { Przewodni projekt UE „Mło- } \\
\text { dzież w drodze” ma na celu po- } \\
\text { prawę wyników systemów } \\
\text { kształcenia oraz podniesienie } \\
\text { atrakcyjności europejskiego } \\
\text { szkolnictwa wyższego na are- } \\
\text { nie międzynarodowej. }\end{array}$ & $\begin{array}{l}\text { Przewodni projekt UE „Polityka prze- } \\
\text { mysłowa w erze globalizacji” ma na } \\
\text { celu poprawę otoczenia biznesu, szcze- } \\
\text { gólnie w odniesieniu do MŚP, oraz } \\
\text { wspieranie rozwoju silnej i zrówno- } \\
\text { ważonej bazy przemysłowej, przygoto- } \\
\text { wanej do konkurowania na rynkach } \\
\text { światowych. }\end{array}$ & $\begin{array}{l}\text { Przewodni projekt UE „Europejski } \\
\text { program walki z ubóstwem” ma na celu } \\
\text { zapewnienie spójności społecznej i te- } \\
\text { rytorialnej, tak aby korzyści płynace ze } \\
\text { wzrostu gospodarczego i zatrudnienia } \\
\text { były szeroko dostępne, a osoby ubogie } \\
\text { i wykluczone społecznie mogły żyć } \\
\text { godniei aktywnie uczestniczyć w życiu } \\
\text { społecznym. }\end{array}$ \\
\hline \multicolumn{3}{|l|}{$\begin{array}{l}\text { SPOEECZEŃSTWO } \\
\text { CYFROWE }\end{array}$} \\
\hline $\begin{array}{l}\text { Przewodni projekt UE „Euro- } \\
\text { pejska agenda cyfrowa” ma na } \\
\text { celu upowszechnienie szybkiego } \\
\text { Internetu oraz umożliwienie go- } \\
\text { spodarstwom domowym i przed- } \\
\text { siębiorstwom czerpanie korzyści } \\
\text { z jednolitego rynku cyfrowego. }\end{array}$ & & \\
\hline
\end{tabular}


Zalącznik 2

\section{STRUKTURA STRATEGII EUROPA 2020}

\begin{tabular}{|c|c|c|}
\hline $\begin{array}{l}\text { Ogólna struktura } \\
\text { instytucyjna }\end{array}$ & \multicolumn{2}{|c|}{$\begin{array}{l}\text { Zintegrowane wytyczne określające zakres priorytetów UE, w tym najważniejsze cele, } \\
\text { jakie UE chce osiągnąć do roku } 2020 \text { i jakie trzeba przelożyć na cele krajowe }\end{array}$} \\
\hline \multirow[t]{3}{*}{ Realizacja } & Sprawozdania krajowe & Podejście tematyezne \\
\hline & $\begin{array}{l}\text { Cel: pomóc państwom członkowskim w opra- } \\
\text { cowaniu i realizacji strategii wyjścia z kryzy- } \\
\text { su umożliwiających przywrócenie stabilności } \\
\text { makroekonomicznej, określenie krajowych } \\
\text { punktów przeciążenia i powrót do trwałego } \\
\text { wzrostu i stabilnych finansów publicznych }\end{array}$ & $\begin{array}{l}\text { Cel: osiągnąć najważniejsze cele uzgodnione } \\
\text { na poziomie UE, łącząc działania na poziomie } \\
\text { unijnym z działaniami krajowymi. } \\
\text { Podejście: strategiczna rola sektorowych } \\
\text { kładów Rady w nadzorowaniu i analizowaniu } \\
\text { postępów w osiąganiu uzgodnionych celów. }\end{array}$ \\
\hline & $\begin{array}{l}\text { Podejście: bardziej szczegółowa ocena naj- } \\
\text { większych problemów makroekonomicznych, } \\
\text { przed jakimi stoją państwa członkowskie, } \\
\text { z uwzględnieniem wzajemnych oddziaływań } \\
\text { między państwami i obszarami polityki. } \\
\text { Instrumenty: sprawozdania państw człon- } \\
\text { kowskich przedstawiane w ramach progra- } \\
\text { mów stabilności i konwergencji; oddzielne, } \\
\text { ale zsynchronizowane zalecenia dotyczące } \\
\text { polityki budżetowej (zawarte w opiniach na } \\
\text { temat programów stabilności i konwergencji) } \\
\text { oraz nierównowagi makroekonomicznej i prze- } \\
\text { szkód w rozwoju, zgodnie z ogólnymi wy- } \\
\text { tycznymi polityki gospodarczej (art. } 121 \text { ust. 2) }\end{array}$ & $\begin{array}{l}\text { Instrumenty: sprawozdania państw członko- } \\
\text { wskich przedstawiane w ramach poprawionych } \\
\text { krajowych programów reform, zawierające } \\
\text { informacje o przeszkodach w rozwoju i postę- } \\
\text { pie w osiąganiu celów; wskazówki wydawane } \\
\text { na poziomie UE w formie zaleceń, zgodnie } \\
\text { z ogólnymi wytycznymi polityki gospodar- } \\
\text { czej (art. 121 ust. 2) i wytycznymi do- } \\
\text { tyczącymi zatrudnienia (art. 148). }\end{array}$ \\
\hline
\end{tabular}

\section{Załącznik III}

PROPONOWANY HARMONOGRAM 2010-2012

2010

Komisja Europejska

Propozycje ogólnego ksztaltu strategii EUROPA 2020

Wiosenny szczyt Rady Europejskiej

Uzgodnienie ogólnego podejścia i zakresu najważniejszych celów UE

Komisja Europejska

Propozycje zintegrowanych wytycznych dla strategii EUROPA 2020

Parlament Europejski

Debata nad strategią i opinia w sprawie zintegrowanych wytycznych

Rada Ministrów

Dopracowanie najważniejszych parametrów (cele UE/cele krajowe, projekty przewodnie, zintegrowane wytyczne) 
Czerwcowy szczyt Rady Europejskiej

Zatwierdzenie strategii EUROPA 2020, potwierdzenie celów UE i celów krajowych oraz zaaprobowanie zintegrowanych wytycznych

Komisja Europejska

Wskazówki operacyjne dotyczące kolejnych działań w ramach strategii EUROPA 2020

Jesienny szczyt Rady Europejskiej

Szczegółowa dyskusja nad wybranym zagadnieniem tematycznym (np. B+R i innowacja)

Państwa członkowskie

Programy stabilności i konwergencji oraz krajowe programy reform

\section{1}

Komisja Europejska

Roczne sprawozdanie na wiosenny szczyt europejski, opinie dotyczące programów stabilności i konwergencji oraz propozycje zaleceń

Rada Ministrów

Analiza przedstawionych przez Komisję propozycji zaleceń, spotkanie Rady ECOFIN w sprawie paktu stabilności i wzrostu

Parlament Europejski

Posiedzenie plenarne i przyjęcie rezolucji

Wiosenny szczyt Rady Europejskiej

Ocena postępów i wyznaczenie strategicznych kierunków

Państwa członkowskie, Komisja Europejska, Rada

Uzupełnienie zaleceń, realizacja reform i składanie sprawozdań

\section{2}

Ta sama procedura, ze szczególnym naciskiem na monitorowanie postępów 